\title{
Article
}

\section{Recycling Rusty Iron with Natural Zeolite Heulandite to Create a Unique Nanocatalyst for Green Hydrogen Production}

\author{
Mohamed Shaban ${ }^{1,2, *(\mathbb{D})}$, Mohammad BinSabt ${ }^{3}$, Ashour M. Ahmed ${ }^{2}\left(\mathbb{B}\right.$ and Fatma Mohamed ${ }^{2,4}$ \\ 1 Department of Physics, Faculty of Science, Islamic University in Madinah, Al-Madinah Al-Munawarah 42351, \\ Saudi Arabia \\ 2 Nanophotonics and Applications (NPA) Lab, Physics Department, Faculty of Science, Beni-Suef University, \\ Beni-Suef 62514, Egypt; ashour.elshemey@gmail.com (A.M.A.); f_chem2010@yahoo.com (F.M.) \\ 3 Chemistry Department, Faculty of Science, Kuwait University, P.O. Box 5969, Safat 13060, Kuwait; \\ Mohammad.binsabt@ku.edu.kw \\ 4 Polymer Research Laboratory, Chemistry Department, Faculty of Science, Beni-Suef University, \\ Beni-Suef 62514, Egypt \\ * Correspondence: mssfadel@aucegypt.edu
}

check for updates

Citation: Shaban, M.; BinSabt, M.; Ahmed, A.M.; Mohamed, F. Recycling Rusty Iron with Natural Zeolite Heulandite to Create a Unique Nanocatalyst for Green Hydrogen Production. Nanomaterials 2021, 11, 3445. https://doi.org/ $10.3390 /$ nano11123445

Academic Editors: Domenica Tonelli and Isacco Gualandi

Received: 6 October 2021

Accepted: 16 November 2021

Published: 20 December 2021

Publisher's Note: MDPI stays neutral with regard to jurisdictional claims in published maps and institutional affiliations.

Copyright: (c) 2021 by the authors. Licensee MDPI, Basel, Switzerland. This article is an open access article distributed under the terms and conditions of the Creative Commons Attribution (CC BY) license (https:/ / creativecommons.org/licenses/by/ $4.0 /)$.

\begin{abstract}
Corrosion-induced iron rust causes severe danger, pollution, and economic problems. In this work, nanopowders of $\mathrm{Fe}_{2} \mathrm{O}_{3}$ and $\mathrm{Fe}_{2} \mathrm{O}_{3}$ /zeolite are synthesized for the first time using rusted iron waste and natural zeolite heulandite by chemical precipitation. The chemical composition, nanomorphologies, structural parameters, and optical behaviors are investigated using different techniques. The $\mathrm{Fe}_{2} \mathrm{O}_{3}$ /zeolite nanocomposite showed smaller sizes and greater light absorption capability in visible light than $\mathrm{Fe}_{2} \mathrm{O}_{3}$ nanopowder. The XRD pattern shows crystalline hematite $\left(\alpha-\mathrm{Fe}_{2} \mathrm{O}_{3}\right)$ with a rhombohedral structure. The crystallite sizes for the plane (104) of the $\mathrm{Fe}_{2} \mathrm{O}_{3}$ and $\mathrm{Fe}_{2} \mathrm{O}_{3}$ /zeolite are 64.84 and $56.53 \mathrm{~nm}$, respectively. The $\mathrm{Fe}_{2} \mathrm{O}_{3}$ and $\mathrm{Fe}_{2} \mathrm{O}_{3} /$ zeolite have indirect bandgap values of 1.87 and $1.91 \mathrm{eV}$ and direct bandgap values of 2.04 and $2.07 \mathrm{eV}$, respectively. $\mathrm{Fe}_{2} \mathrm{O}_{3}$ and $\mathrm{Fe}_{2} \mathrm{O}_{3}$ /zeolite nanophotocatalysts are used for solar photoelectrochemical (PEC) hydrogen production. The $\mathrm{Fe}_{2} \mathrm{O}_{3}$ /zeolite exhibits a PEC catalytic hydrogen production rate of $154.45 \mathrm{mmol} / \mathrm{g} . \mathrm{h}$ @ $1 \mathrm{~V}$ in $0.9 \mathrm{M} \mathrm{KOH}$ solution, which is the highest value yet for $\mathrm{Fe}_{2} \mathrm{O}_{3}$-based photocatalysts. The photocurrent density of $\mathrm{Fe}_{2} \mathrm{O}_{3}$ / zeolite is almost two times that of $\mathrm{Fe}_{2} \mathrm{O}_{3}$ catalyst, and the IPCE (incident photon-to-current conversion efficiency) reached $\sim 27.34 \% @ 307 \mathrm{~nm}$ and $1 \mathrm{~V}$. The electrochemical surface area (ECSA) values for $\mathrm{Fe}_{2} \mathrm{O}_{3}$ and $\mathrm{Fe}_{2} \mathrm{O}_{3} /$ zeolite photocatalysts were 7.414 and $21.236 \mathrm{~m}^{2} / \mathrm{g}$, respectively. The rate of hydrogen production for $\mathrm{Fe}_{2} \mathrm{O}_{3} /$ zeolite was $154.44 \mathrm{mmol} \mathrm{h}^{-1} / \mathrm{g}$. This nanophotocatalyst has a very low PEC corrosion rate of $7.6 \mathrm{pm} /$ year; it can retain $\sim 97 \%$ of its initial performance. Therefore, the present research can be applied industrially as a cost-effective technique to address two issues at once by producing solar hydrogen fuel and recycling the rusted iron wires.
\end{abstract}

Keywords: rusted iron; $\mathrm{Fe}_{2} \mathrm{O}_{3}$ /zeolite nanocomposite; water splitting; hydrogen production; photocatalyst

\section{Introduction}

Fossil fuel burning is the major source of $\mathrm{CO}_{\mathrm{x}}$ emissions $\left(\mathrm{CO}_{2}\right.$ and $\left.\mathrm{CO}\right)$ in atmospheric air, which causes global warming. The resulting air pollution can have catastrophic effects on humans and animals alike [1,2]. Hydrogen fuel is a carbon-free, renewable, and environmentally friendly source of energy that can be used as an ideal alternative to fossil fuels.

Therefore, the developments of effective techniques for large hydrogen fuel production at reasonable cost are important research areas. The photoelectrochemical (PEC) hydrogen production utilizing semiconductor-based catalysts is a promising technique to meet these requirements. In the PEC process, the photocatalyst produces an electron/hole pair after absorbing a photon, which is then isolated, transported, and contributed to the cathodic hydrogen evolution/anodic oxygen evolution reactions at applied voltage [3,4]. 
Under incident light with a suitable wavelength, electron/hole pairs are created in the semiconductor. The holes reacted with $\mathrm{H}_{2} \mathrm{O}$ to generate hydroxyl radical $(\mathrm{OH})$. The electrons can react with $\mathrm{O}_{2}$ to produce superoxide radicals $\left(\mathrm{O}_{2}^{-}\right)$. These reactive species are primarily responsible for the water splitting and hydrogen production [5]. There are several semiconductor materials such as $\mathrm{WO}_{3}, \mathrm{ZrO}_{2}, \mathrm{In}_{2} \mathrm{O}_{3}, \mathrm{SnO}_{2}, \mathrm{Fe}_{2} \mathrm{O}_{3}, \mathrm{TiO}_{2}, \mathrm{ZnO}, \mathrm{CuO}$, and $\mathrm{CdS}$ that were applied to upgrade the PEC performance. Among them, $\mathrm{Fe}_{2} \mathrm{O}_{3}$ is used as a photocatalyst for the PEC due to its hard solubility, high chemical stability, low cost, and massive abundance [6,7]. Additionally, it is a non-toxic and ecologically benign substance, all of which are required for large-scale solar energy conversion at a reasonable cost. $\mathrm{Fe}_{2} \mathrm{O}_{3}$ has semiconducting properties with a narrow bandgap $(\sim 2.1 \mathrm{eV})$. This low bandgap enables it to be a good photocatalyst in the visible region. However, this material has many drawbacks that limit its application in practical photocatalytic such as low diffusion lengths of holes, poor conductivity, fast electron-hole recombination, poor adsorption property, agglomeration, and difficulty in being recovered [8]. Several studies immobilized the $\mathrm{Fe}_{2} \mathrm{O}_{3}$ nanoparticles on different supports, such as activated carbon, silica, alumina, clay, and zeolite to overcome these disadvantages. Among them, zeolite is of particular interest because, besides its semiconducting nature, it has a high adsorption capacity against organic contaminants. Zeolite possesses ionic exchange properties that are idyllic for the adsorption/degradation of organic dyes $[9,10]$. It also has enormous unique areas, adjustable hydrophobicity/hydrophilicity, and photochemical stability [11,12]. In addition, zeolite is low-cost, abundant, and bio-compatible. Zeolite is a monocrystal mineral composed of $\mathrm{Si}$ and $\mathrm{Al}$ atoms in a tetrahedral arrangement $\left(\mathrm{TO}_{4} ; \mathrm{T}=\mathrm{Si}, \mathrm{Al}\right)$ [13]. It can be used in many applications such as cement, porcelain, electronics, and water splitting for the production of hydrogen. When a semiconductor is supported on a suitable support, such as zeolites, the semiconductor particles are evenly dispersed, preventing them from aggregating.

In the past few years, zeolite was used as a support for semiconductor-based PEC catalysts to enhance the hydrogen production rate. The $\mathrm{ZnCo} / \mathrm{CdS} /$ zeolite heterostructure was prepared and optimized by Jia-Hui et al. to achieve photocatalytic hydrogen activity 59 times greater than that of pristine $\mathrm{CdS}$, which is ascribed to zeolite's role in improving the separation and transportation capacity of photo-generated charge carriers [14]. Yue and Khan reported the formation of vacant sites on the zeolite surface due to the exchange of ions in titano-zeolites, which assists the hydrogen photoproduction [15]. Additionally, Pt/zeolite and $\mathrm{Cu}$ /zeolite were prepared and applied for the hydrogen [16,17]. Owing to its large use in many applications, iron has been considered one of the primary manufacturing materials over the past decades. Iron corrosion happens after the iron contacts the air moisture. The corrosion of iron structures causes millions of tons of rusty waste to form, resulting in danger, environmental pollution, and economic issues. Therefore, considering the worldwide vast use of iron wires, the recycling/reuse of rusty waste is predicted to substantially decrease the wastes amounts, leading to the creation of recycling-oriented societies.

Hence, the $\mathrm{Fe}_{2} \mathrm{O}_{3}$ nanoparticles production from rusted iron wastes can thus be considered in many fields as a viable alternative to synthetic and natural iron supplies. Previously, different techniques have been used to prepare $\mathrm{Fe}_{2} \mathrm{O}_{3}$ nanostructures such as sol-gel, spray pyrolysis, hydrothermal, chemical vapor deposition, and thermal evaporation [18,19]. Most of these methods require complicated reactions, high energy intakes, and poor product yield. Since no special additives or equipment are needed, chemical precipitation is considered the most effective and low-cost technique for the production of $\mathrm{Fe}_{2} \mathrm{O}_{3}$.

The objective of this work is to replace the iron precursors with rust wastes as a source of iron for the synthesis of $\mathrm{Fe}_{2} \mathrm{O}_{3}$ and $\mathrm{Fe}_{2} \mathrm{O}_{3}$ /zeolite nanopowder by chemical precipitation. The prepared $\mathrm{Fe}_{2} \mathrm{O}_{3}$ /zeolite nanocomposite is applied for the PEC production of solar hydrogen fuel. The photon-to-electron and photon-to-hydrogen conversion efficiencies are calculated for $\mathrm{Fe}_{2} \mathrm{O}_{3}$ and $\mathrm{Fe}_{2} \mathrm{O}_{3}$ /zeolite. 


\section{Materials and Experimental Procedures}

\subsection{Materials}

Natural zeolite was delivered from a zeolite mine located southwest of Taiz (Al-Ahyuq region, Taiz City, Yemen). $\mathrm{HCl}$ and $\mathrm{KOH}$ were received from El-Nasr Company (Cairo, Egypt). All chemicals were at least 99 percent pure, and they were utilized just as they were bought, with no further purification. Rusted iron wires were collected from construction sites.

\subsection{Preparation of the Zeolite, $\mathrm{Fe}_{2} \mathrm{O}_{3}$ and $\mathrm{Fe}_{2} \mathrm{O}_{3} /$ Zeolite}

Rusted iron wire fragments were collected from construction sites in Egypt's Beni-Suef City. The average length of wires is about $30 \mathrm{~cm}$ with a diameter of about $1 \mathrm{~cm}$. The color of the wires is dark red. Upon cutting to small fragments, the rusted wires were washed using deionized (DI) water. A total of $10 \mathrm{~g}$ of these pieces was dissolved in $80 \mathrm{~mL}$ of $\mathrm{HCl}$ $(37 \%)$ and $170 \mathrm{~mL}$ DI water under magnetic stirring at $85^{\circ} \mathrm{C}$. The solution was filtered, and $20 \mathrm{~mL}$ of $\mathrm{H}_{2} \mathrm{O}_{2}(30 \%)$ was added to the obtained pale green-colored solution. Under intense 60 min-stirring, the ammonia solution was dropped to the iron solution. In a glass beaker with a volume of $200 \mathrm{~mL}$, the iron was precipitated. Varying volumes of ammonium hydroxide solution $\left(10,15\right.$, and $20 \mathrm{~mL}$ ) were used to prepare $\mathrm{Fe}_{2} \mathrm{O}_{3}$ powders with different crystallite sizes. The samples were labeled as $\mathrm{Fe}_{2} \mathrm{O}_{3}$ (I), $\mathrm{Fe}_{2} \mathrm{O}_{3}$ (II), and $\mathrm{Fe}_{2} \mathrm{O}_{3}$ (III), where I, II, and III refer to the 10, 15, and $20 \mathrm{~mL}$ of ammonia supplied to the reaction, respectively. Then, the resulting precipitated iron powder was filtrated before washing and drying. Then, the collected powder was heated for $3 \mathrm{~h}$ at $500{ }^{\circ} \mathrm{C}$. A total of $15 \mathrm{~g}$ of raw zeolite mine was washed with DI water and dried in the air. Then, it was triggered mechanically by ball milling. Table 1 shows the conditions for ball milling parameters.

Table 1. The ball milling conditions for preparing zeolite.

\begin{tabular}{ll}
\hline Condition & Description \\
\hline Vessel size & $15 \mathrm{~cm}$ \\
\hline Diameter balls & from 1.11 to $1.75 \mathrm{~cm}$ \\
\hline Materials of vessels & stainless steel \\
\hline Materials of balls & porcelain \\
\hline Ball/precipitate mass ratio & $8: 1$ mass ratio \\
\hline Speed & $5000 \mathrm{rpm}$ \\
\hline Time & $5 \mathrm{~h}$ \\
\hline
\end{tabular}

For preparing $\mathrm{Fe}_{2} \mathrm{O}_{3}$ / zeolite nanocomposite with optimized composition, different weight ratios of activated zeolite and iron powder $\left(\mathrm{Fe}_{2} \mathrm{O}_{3}\right.$ (III)) were added to $100 \mathrm{~mL}$ of DI water under ultrasonication for $3 \mathrm{~h}$. The total weight of $\mathrm{Fe}_{2} \mathrm{O}_{3} /$ zeolite nanocomposite is kept at $2 \mathrm{~g}$. The weight ratios were $0.2 / 1.8,0.6 / 1.4,0.8 / 1.2,1.0 / 1.0,1.2 / 0.8,1.4 / 0.6$, and 1.8/0.2. The resulting mixtures were dried at $80{ }^{\circ} \mathrm{C}$ for $12 \mathrm{~h}$. Finally, the $\mathrm{Fe}_{2} \mathrm{O}_{3} /$ zeolite nanocomposites were calcinated at $550{ }^{\circ} \mathrm{C}$ for $240 \mathrm{~min}$. The nanopowders were recorded as $x \mathrm{Fe}_{2} \mathrm{O}_{3}$ /yzeolite, where $\mathrm{x}$ and $\mathrm{y}$ were denoted to the adding weight of $\mathrm{Fe}_{2} \mathrm{O}_{3}$ and zeolite, respectively. The synthesis steps of $\mathrm{Fe}_{2} \mathrm{O}_{3} /$ zeolite nanocomposite are illustrated by a schematic in Figure 1.

\subsection{Characterizations}

A Philips X'Pert Pro MRD diffractometer (XRD, $\lambda=0.154 \mathrm{~nm}$, Philips X'Pert Pro MRD, Royston, UK) was utilized to obtain the X-ray diffraction (XRD) patterns of the samples with an operating voltage of $40 \mathrm{kV}$ in the range from $5^{\circ}$ to $80^{\circ}$. The samples nanomorphologies were examined using a JEOL JSM-5400LV scanning electron microscope (SEM, JEOL, Tokyo, Japan). The chemical compositions were investigated by Energy Dispersive X-ray spectrometry (EDX, JEOL JED-2300 SEM, Tokyo, Japan). FT-IR (Fourier 
transform-infrared) spectra of $\mathrm{Fe}_{2} \mathrm{O}_{3}$ and $\mathrm{Fe}_{2} \mathrm{O}_{3}$ / zeolite nanocomposite were examined through Vertex 70 FTIR-FT Raman spectrometer (Billerica, MA, USA). The UV/Vis optical properties of the samples were scanned in the range 250-900 nm with an increment of $1 \mathrm{~nm}$ by UV-Vis double beam spectrophotometer (LAMBDA 950, PerkinElmer Inc., Waltham, MA, USA). About $0.05 \mathrm{~g}$ nanopowder is dispersed in $10 \mathrm{~mL}$ of dimethylformamide by ultrasonic for $3 \mathrm{~h}$. Then, $3 \mathrm{~mL}$ of the prepared suspension is used for UV-Vis spectroscopy scanning in a standard quartz cuvette.

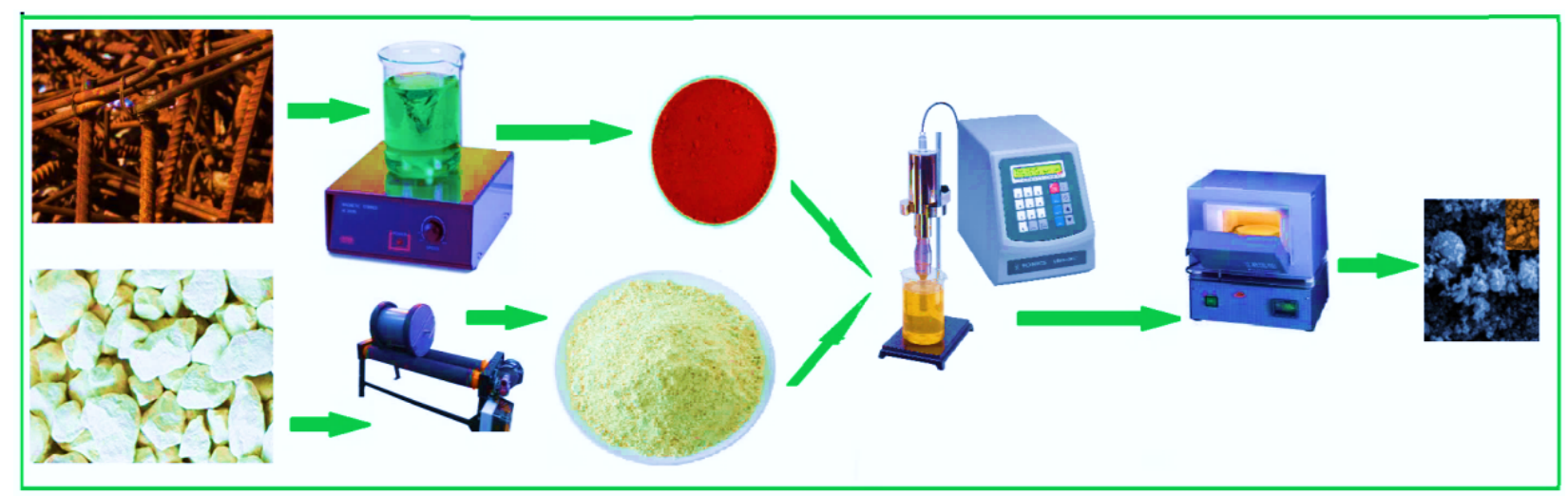

Figure 1. Schematic of the synthesis steps of $\mathrm{Fe}_{2} \mathrm{O}_{3} /$ zeolite.

\subsection{PEC Water Splitting Measurements}

The PEC behaviors in $0.9 \mathrm{M} \mathrm{KOH}(100 \mathrm{~mL}, \mathrm{pH} 13.5)$ were measured at room temperature $\left(20^{\circ} \mathrm{C}\right)$ utilizing a Keithly measuring-source unit (Tektronix Company, model: 2400, Beaverton, OR, USA) with LabTracer software and a $400 \mathrm{~W}$ metal-halide lamp (New-port, 66926-500HX-R07, Newport, UK) with a set of linear optical filters (307-636 nm). The sweeping scan rate was $1 \mathrm{mV} / \mathrm{s}$. $\mathrm{Fe}_{2} \mathrm{O}_{3}$ and $\mathrm{Fe}_{2} \mathrm{O}_{3} /$ zeolite doses of $1 \mathrm{~g}$ were used. The PEC current density-voltage $(\mathrm{J}-\mathrm{V})$ curves were quantified in darkness, monochromatic, and white light exposure conditions. In addition, the $\mathrm{Fe}_{2} \mathrm{O}_{3}$ / zeolite stability was investigated using current density-time $(\mathrm{J}-\mathrm{t})$ measurements. All PEC measurements were carried out in a quartz cell of volume $150 \mathrm{~mL}$.

\section{Results and Discussion}

\subsection{Photocatalysts Characterization}

\subsubsection{Structural of $\mathrm{Fe}_{2} \mathrm{O}_{3}$ and $\mathrm{Fe}_{2} \mathrm{O}_{3} /$ Zeolite}

The crystallinity and phase of the $\mathrm{Fe}_{2} \mathrm{O}_{3}$, zeolite, and $\mathrm{Fe}_{2} \mathrm{O}_{3}$ / zeolite nanocomposite were identified using XRD analysis as seen in Figure 2A. Zeolite's distinctive XRD peaks, in Figure $2 \mathrm{~A}$, are noted at $2 \theta \sim 9.68^{\circ}, 11.00^{\circ}, 17.16^{\circ}, 18.87^{\circ}, 22.24^{\circ}, 26.01^{\circ}, 27.97,29.84^{\circ}$, $31.83^{\circ}, 35.88^{\circ}, 47.58^{\circ}, 61.76^{\circ}$, and $67.31^{\circ}$. Such peaks correspond to the crystallographic plane (020), (200), (111), (-131), (-222), (-422), (-351), (-530), (-202), (005), (311), and (223), based on PDF card No. 00-053-1176, respectively. Based on the XRD card, the type of zeolite is heulandite.

For iron oxide, the XRD pattern in Figure 2A suggests that crystalline hematite ( $\alpha$ $\mathrm{Fe}_{2} \mathrm{O}_{3}$ ) with rhombohedral structure (space group: R-3c) was formed according to the standard card No. 01-089-0597. This agrees with the previously reported data for $\mathrm{Fe}_{2} \mathrm{O}_{3}$ [20]. The pattern of $\mathrm{Fe}_{2} \mathrm{O}_{3}$ nanoparticles displays the core $\alpha-\mathrm{Fe}_{2} \mathrm{O}_{3}$ feature peaks. These peaks are found at $33.00^{\circ}, 35.39^{\circ}, 49.32^{\circ}, 53.84^{\circ}$, and $63.74^{\circ}$ and correspond to the planes (104), (110), (024), (116), and (300). The sharp and intensive peaks indicate the high purity and crystallinity of the synthesized hematite nanoparticles using bulk Fe-based rust. These XRD data are similar to previously synthesized iron oxide in many works using synthetic precursors [21-23]. From the estimated FWHM of the strongest (104) and (110), the crystallite sizes of the $\mathrm{Fe}_{2} \mathrm{O}_{3}$ nanoparticles were estimated based on the Debye-Scherrer relation to be $\sim 64.84$ and $50.46 \mathrm{~nm}$, respectively. 


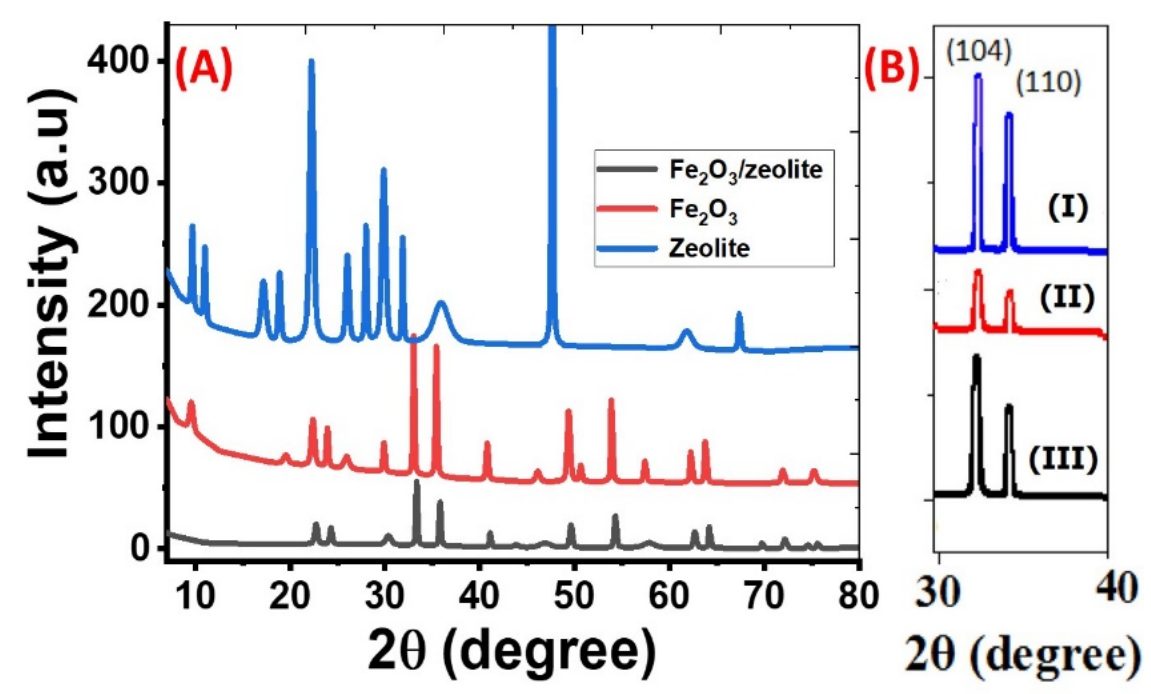

Figure 2. (A) XRD patterns of zeolite, $\mathrm{Fe}_{2} \mathrm{O}_{3}$, and $\mathrm{Fe}_{2} \mathrm{O}_{3}$ / zeolite nanocomposite; and (B) XRD (104) and (110) peaks of $\mathrm{Fe}_{2} \mathrm{O}_{3}$ (I), $\mathrm{Fe}_{2} \mathrm{O}_{3}$ (II), and $\mathrm{Fe}_{2} \mathrm{O}_{3}$ (III).

For zeolite, many distinct peaks are observed at $22.72^{\circ}(101), 41.05^{\circ}(210)$, and $54.24^{\circ}$ (221), corresponding to tetragonal zeolite $\left(\mathrm{Al}_{0.05} \mathrm{Si}_{0.95} \mathrm{O}_{2}\right)$ according to card No. 04-0028520. As illustrated in Figure 2A, the main core features of XRD patterns of $\mathrm{Fe}_{2} \mathrm{O}_{3}$ and $\mathrm{Fe}_{2} \mathrm{O}_{3} /$ zeolite are very close, indicating that the introduction of zeolite did not affect the structural properties of the $\mathrm{Fe}_{2} \mathrm{O}_{3}$ photocatalyst. However, the coupling of $\mathrm{Fe}_{2} \mathrm{O}_{3}$ with zeolite leads to an increase in the FWHM and a slight shift in the plane position of the $\mathrm{Fe}_{2} \mathrm{O}_{3}$ toward higher angles after coupling. Hence, the crystallites sizes of (104) and (110) peaks for $\mathrm{Fe}_{2} \mathrm{O}_{3}$ nanoparticles were decreased to 56.53 and $47.85 \mathrm{~nm}$ for $\mathrm{Fe}_{2} \mathrm{O}_{3} /$ zeolite nanocomposite. Similar behavior was reported for hydrothermally prepared $4 \mathrm{~A}$-zeolite supported alpha- $\mathrm{Fe}_{2} \mathrm{O}_{3}$ [24]. In addition, the relative intensities of the diffraction peaks of $\mathrm{Fe}_{2} \mathrm{O}_{3}$ /zeolite nanocomposite became weaker than the peaks of $\mathrm{Fe}_{2} \mathrm{O}_{3}$, indicating a change in the crystallinity of the photocatalyst due to the distribution of $\mathrm{Fe}_{2} \mathrm{O}_{3}$ on the surface of the zeolite [25]. The structural parameters such as crystallite size (D), interplanar distance $(\mathrm{d})$, dislocation density $(\delta)$, and microstrain $(\varepsilon)$ are calculated for the highest two peaks, (104) and (110), utilizing the XRD patterns of $\mathrm{Fe}_{2} \mathrm{O}_{3}$ and $\mathrm{Fe}_{2} \mathrm{O}_{3}$ /zeolite nanopowders. Besides peak position, peak height, and relative intensity, the obtained values are displayed in Table 2. For the two planes (104) and (110), the value of microstrain increases while $\mathrm{d}$-spacing decreases after loading the zeolite with $\mathrm{Fe}_{2} \mathrm{O}_{3}$. The strongest peak corresponds to the plane (104), which indicates the preferred growth orientation of hematite. This growth orientation is beneficial to carrier transport [26]. The number of lattice defects was estimated depending on the dislocation density, $\delta$, which refers to the dislocation lines length per unit volume of the crystal. The $\delta$ value is estimated using the relation; $\delta=1 / \mathrm{D}^{2}$. The values of $\delta$ for the $\mathrm{Fe}_{2} \mathrm{O}_{3}$ and $\mathrm{Fe}_{2} \mathrm{O}_{3}$ /zeolite at the preferred orientation (104) are $2.378 \times 10^{-4}$ and $3.129 \times 10^{-4}$ dislocation $/ \mathrm{nm}^{2}$, respectively. The increase in dislocation density proposes the decrease of $\mathrm{Fe}_{2} \mathrm{O}_{3}$ /zeolite crystallinity [27], which strongly influences the photocatalytic properties of the fabricated nanomaterials. This is also confirmed by the decreasing of the XRD peaks intensities after loading $\mathrm{Fe}_{2} \mathrm{O}_{3}$ on zeolite, as seen in Table 2 . The existence of a high density of the defects in the $\mathrm{Fe}_{2} \mathrm{O}_{3}$ /zeolite nanocrystallites can contribute positively to the photocatalytic properties as a result of the active surface area increase and the formation of a high density of the active centers [28]. These active centers may result from the formation of static charge fields about the dislocation lines [29]. 
Table 2. Values of the crystallographic parameters of $\mathrm{Fe}_{2} \mathrm{O}_{3}$ and $\mathrm{Fe}_{2} \mathrm{O}_{3}$ / zeolite nanohybrid.

\begin{tabular}{|c|c|c|c|c|c|c|c|c|}
\hline Parameter & $\begin{array}{l}\text { Planes } \\
\text { (hkl) }\end{array}$ & $\begin{array}{c}\text { Position } \\
\left({ }^{\circ} \text { 2Th.) }\right. \\
\text { (degree) }\end{array}$ & $\begin{array}{l}\text { Height } \\
\text { (cts) }\end{array}$ & $\begin{array}{l}\text { d-Spacing } \\
\text { (A) }\end{array}$ & $\begin{array}{c}\text { Relative } \\
\text { Intensity } \\
(\%)\end{array}$ & $\begin{array}{c}\text { Crystallite } \\
\text { Size } \\
(\mathrm{nm})\end{array}$ & 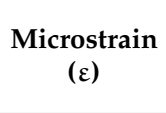 & $\begin{array}{c}\text { Dislocation ( }(\delta) \\
\left(10^{-4} \mathrm{~nm}^{-2}\right)\end{array}$ \\
\hline \multirow{2}{*}{$\mathrm{Fe}_{2} \mathrm{O}_{3}$} & (110) & 35.39 & 83.37 & 2.536 & 89.78 & 50.46 & 0.251 & 3.927 \\
\hline & (104) & 33 & 92.86 & 2.714 & 100 & 64.84 & 0.209 & 2.378 \\
\hline \multirow{2}{*}{$\mathrm{Fe}_{2} \mathrm{O}_{3} /$ zeolite } & (110) & 35.77 & 27.45 & 2.51 & 67.22 & 47.85 & 0.262 & 4.367 \\
\hline & (104) & 33.32 & 40.83 & 2.689 & 100 & 56.53 & 0.238 & 3.129 \\
\hline
\end{tabular}

Figure 2B shows the XRD (104) and (110) peaks of $\mathrm{Fe}_{2} \mathrm{O}_{3}$ (I), $\mathrm{Fe}_{2} \mathrm{O}_{3}$ (II), and $\mathrm{Fe}_{2} \mathrm{O}_{3}$ (III) that were prepared using different amounts of ammonium hydroxide solution $(10,15$, and $20 \mathrm{~mL}$ ). From Figure 2B, the average crystallite size (D) for the highest two planes (104) and (110) were calculated by the Debye-Scherer equation at different amounts of ammonia solution. The average values of $\mathrm{D}$ for $\mathrm{Fe}_{2} \mathrm{O}_{3}$ (I), $\mathrm{Fe}_{2} \mathrm{O}_{3}$ (II), and $\mathrm{Fe}_{2} \mathrm{O}_{3}$ (III) are found to be $57.65,44.12$, and $36.42 \mathrm{~nm}$ respectively. Then, the average crystallite size of $\mathrm{Fe}_{2} \mathrm{O}_{3}$ depends on the volume of used ammonium hydroxide. According to the effective mass model, when particle size is reduced at the nanoscale, quantum confinement has an influence on electrons in nanoparticles. Changing the quantum (crystallite) size can alter the optical characteristics. As a result, the crystallite size is critical to the generation of hydrogen.

\subsubsection{Surface Morphology}

It is well-known that the photocatalytic activity of the photocatalyst is strongly related to its surface morphology. The morphologies of natural zeolite, $\mathrm{Fe}_{2} \mathrm{O}_{3}$, and $\mathrm{Fe}_{2} \mathrm{O}_{3}$ /zeolite nanopowders are examined utilizing the SEM technique as shown in Figure 3.

The SEM images of natural zeolite, Figure 3A, show micro/nano-stones in nonuniform shapes of various sizes. The sizes of stones for zeolite are changed from 21.6 to $3.2 \mu \mathrm{m}$, as seen in the corresponding particle size distribution (left of Figure 4A) of the particle size distribution. The mean particle size is $10.951 \pm 0.820 \mu \mathrm{m}$ with a standard deviation of $6.027 \pm 1.647 \mu \mathrm{m}$. A close look at the image reveals the existence of many small nanoprotrusions/nanograins over zeolite particle surfaces with an average size of $\sim 115 \mathrm{~nm}$. Additionally, there are many small nanopores with a diameter of $\sim 71 \mathrm{~nm}$ on the surface of zeolite with irregular shapes as seen in high magnification Figure 3A. The high surface area due to the porous framework provides a chance to incorporate iron oxide nanoclusters inside the pore cavity of zeolite [30]. Additionally, these pores can adsorb organic pollutants, which can increase photodegradation efficiency.

The $\mathrm{Fe}_{2} \mathrm{O}_{3}$ nanopowder was composed of many nanoparticles with semi-spherical shapes. The SEM image of $\mathrm{Fe}_{2} \mathrm{O}_{3}$ nanoparticles shows that the nanoparticles are small in size, seen in Figure 3B. The corresponding particle size distribution is shown on the left of Figure 3B. Based on Gaussian fitting; the mean size of $\mathrm{Fe}_{2} \mathrm{O}_{3}$ nanoparticle is $113.65 \pm 4.67 \mathrm{~nm}$ with a standard deviation of $14.92 \pm 5.95 \mathrm{~nm}$. These nanoparticles are self-assembled and aggregated to form nanopores of average diameter $\sim 20.99 \mathrm{~nm}$ with a standard deviation of $\pm 6.02 \mathrm{~nm}$, as shown from the inset pore-diameter distribution of Figure 3B.

Fine spherical $\mathrm{Fe}_{2} \mathrm{O}_{3}$ nanoparticles coated the zeolite surface and appeared as homogeneous distributions that produced a nano-sized $\mathrm{Fe}_{2} \mathrm{O}_{3}$ coating surface over zeolite stones after loading zeolite with the intended $\mathrm{Fe}_{2} \mathrm{O}_{3}$ photo-catalyst, Figure $3 \mathrm{C}$. It is also possible that the $\mathrm{Fe}_{2} \mathrm{O}_{3}$ coating was quite homogeneous, with no obvious uncoated zeolite sites. The size of the $\mathrm{Fe}_{2} \mathrm{O}_{3}$ nanoparticles seems to be decreased after loading on zeolite compared to the free-standing $\mathrm{Fe}_{2} \mathrm{O}_{3}$ nanopowder. The size distribution of the supported $\mathrm{Fe}_{2} \mathrm{O}_{3}$ nanoparticles on the surface of zeolite, left of Figure $3 \mathrm{C}$, indicates an average value of $88.94 \pm 1.67 \mathrm{~nm}$. Additionally, the high magnification SEM image, inset of Figure 3C, shows a more homogeneous pore-diameter distribution with a mean value of $35.50 \pm 2.25 \mathrm{~nm}$. 

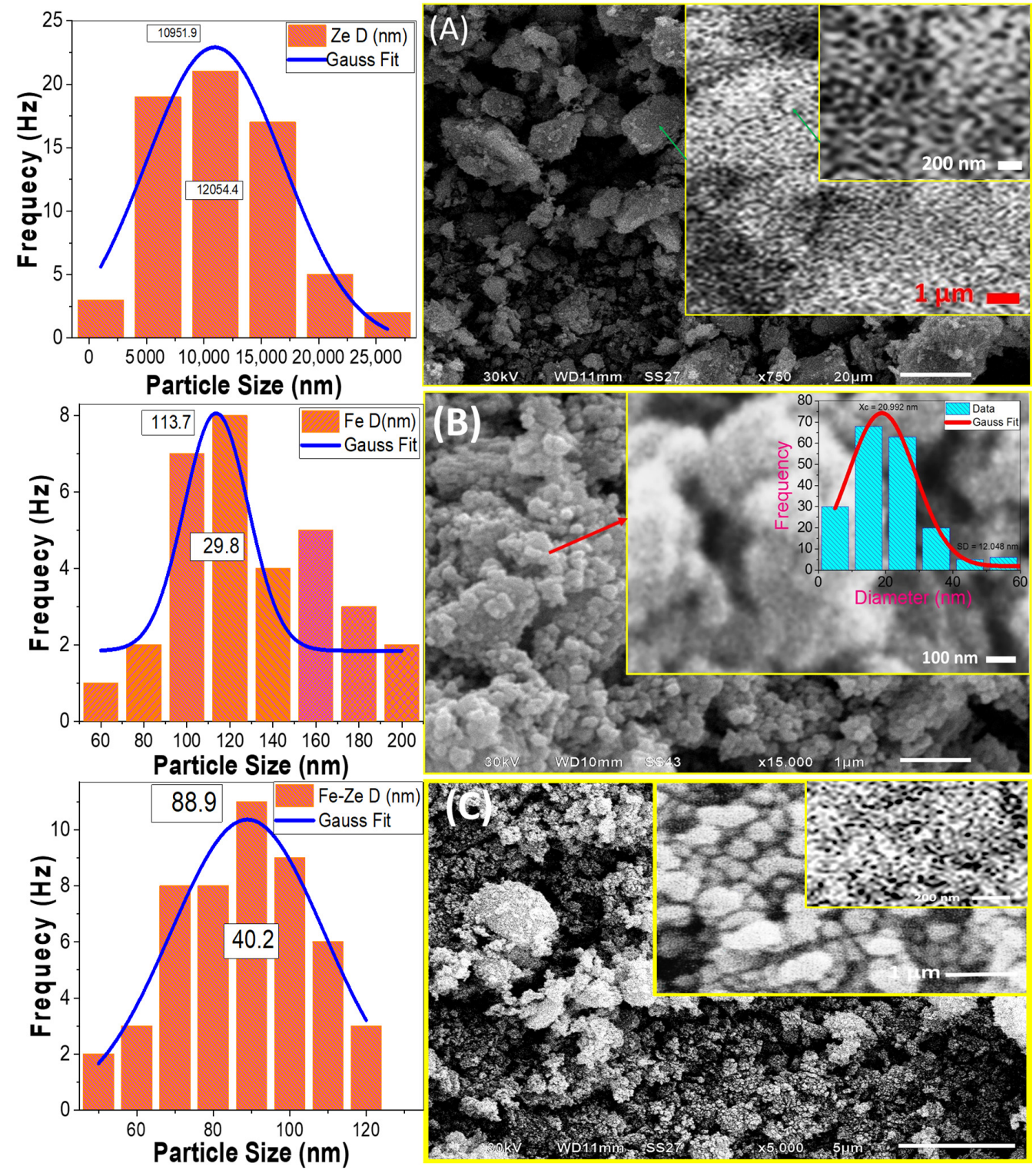

Figure 3. SEM micrographs and the corresponding particle size distribution for (A) natural zeolite, (B) $\mathrm{Fe}_{2} \mathrm{O}_{3}$, and (C) $\mathrm{Fe}_{2} \mathrm{O}_{3}$ / zeolite. The inset of (B) shows the pore diameter distribution.

The interlock between $\mathrm{Fe}_{2} \mathrm{O}_{3}$ nanoparticles and their precipitation over the zeolite is expected to be beneficial for PEC activity. Haileyesus et al. reported that similar interlock structures can offer a rapid migration of the induced electrons and holes to the catalyst surface, which leads to a low probability of recombination [31]. Additionally, the decrease of the particle size to the nanoscale and the widening of the pores can offer a huge effective surface area of $\mathrm{Fe}_{2} \mathrm{O}_{3}$ nanocatalyst. This can offer intensive absorption of the incident light.

\subsubsection{Chemical Compositions of the Photocatalysts}

To identify the chemical compositions of the designed photocatalysts and atomic ratios of the elements, the EDX spectra of zeolite, $\mathrm{Fe}_{2} \mathrm{O}_{3}$, and $\mathrm{Fe}_{2} \mathrm{O}_{3}$ / zeolite nanocomposite were measured and presented in Figure 4. The chemical composition for the zeolite shows the main three elements $(\mathrm{O}, \mathrm{Al}$, and $\mathrm{Si})$ as revealed by EDX analysis. Additionally, small signals for $\mathrm{K}, \mathrm{Ca}$, and $\mathrm{Fe}$ are observed, in addition to a small trace from $\mathrm{Cu}$. These signals are similar to previously reported signals for the zeolite [32]. 


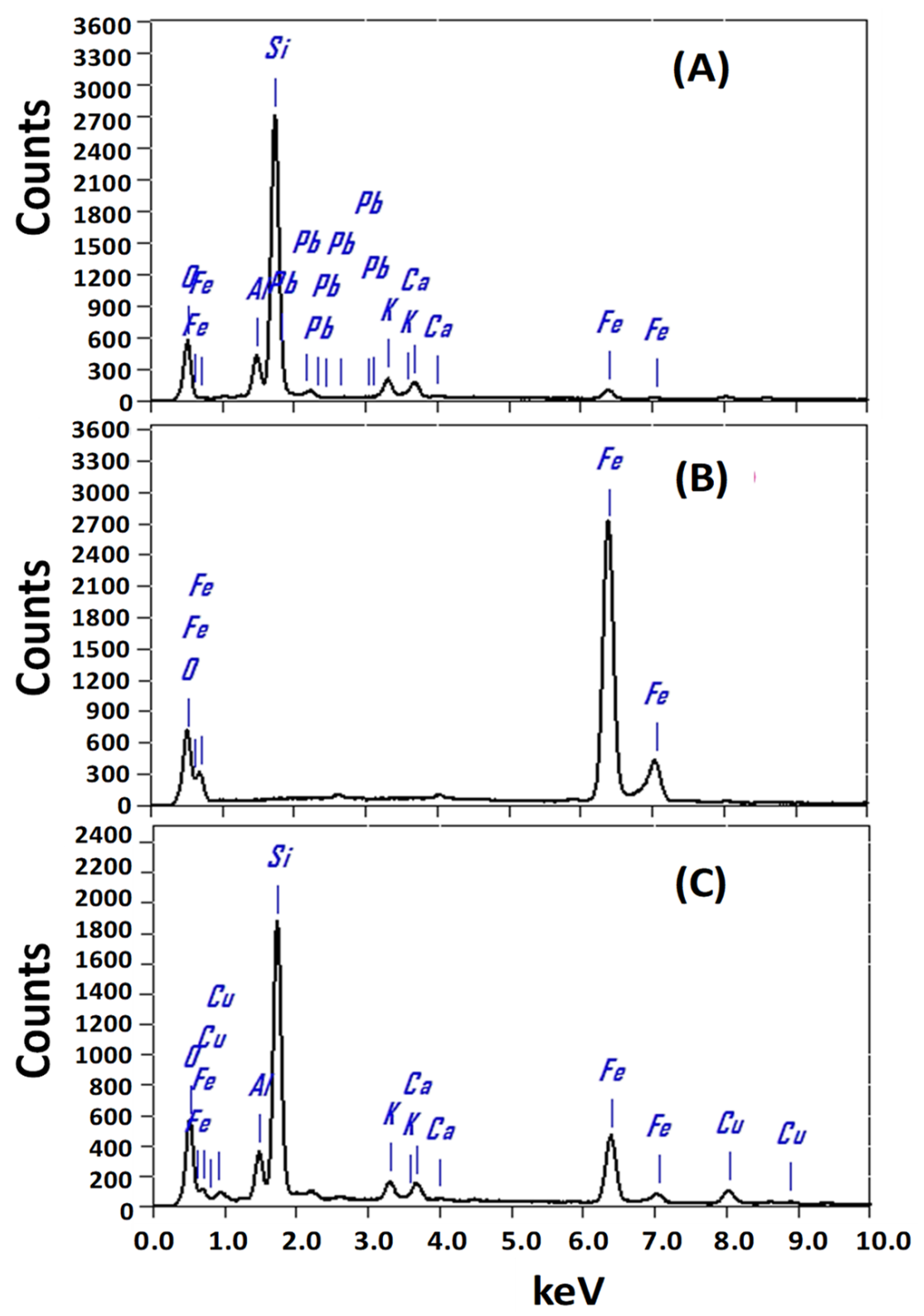

Figure 4. EDX spectrum of (A) zeolite, (B) $\mathrm{Fe}_{2} \mathrm{O}_{3}$, and (C) $\mathrm{Fe}_{2} \mathrm{O}_{3}$ / zeolite nanocomposite.

The EDX analysis of $\mathrm{Fe}_{2} \mathrm{O}_{3}$, Figure $4 \mathrm{~B}$, indicated the presence of $\mathrm{O}(37.62 \%)$ and $\mathrm{Fe}$ $(62.38 \%)$ signals as the main components at around 0.525 and $6.398 \mathrm{keV}$. The atomic ratios of Fe to $\mathrm{O}$ suit the stoichiometry ratios of $\mathrm{Fe}_{2} \mathrm{O}_{3}$ well. This confirms the high purity of the prepared $\mathrm{Fe}_{2} \mathrm{O}_{3}$ nanopowder, which coincides with the XRD results. After loading $\mathrm{Fe}_{2} \mathrm{O}_{3}$ onto zeolite, there are main four characteristic peaks for $\mathrm{O}, \mathrm{Al}, \mathrm{Si}$, and Fe with atomic ratios of $53.12 \%, 6.30 \%, 26.63 \%$, and $9.01 \%$, respectively. This indicates the successive loading of $\mathrm{Fe}_{2} \mathrm{O}_{3}$ onto the surface of the zeolite.

\subsubsection{The Photocatalysts' Optical Properties}

Nanomaterials' optical properties are important characteristics that influence their uses [33,34]. The absorption (A) and transmittance (T) spectra from 250 to $850 \mathrm{~nm}$ of zeolite, $\mathrm{Fe}_{2} \mathrm{O}_{3}$, and $\mathrm{Fe}_{2} \mathrm{O}_{3}$ /zeolite are shown in Figure 5. The zeolite sample has a sharp peak corresponding to a strong absorption band at the UV region (below $\lambda=300 \mathrm{~nm}$ ), as seen in Figure 5A. Then, the absorbance decreases sharply with increasing the wavelength from 280 up to $850 \mathrm{~nm}$. Therefore, the zeolite sample displayed a very low spectral response in the visible region. 

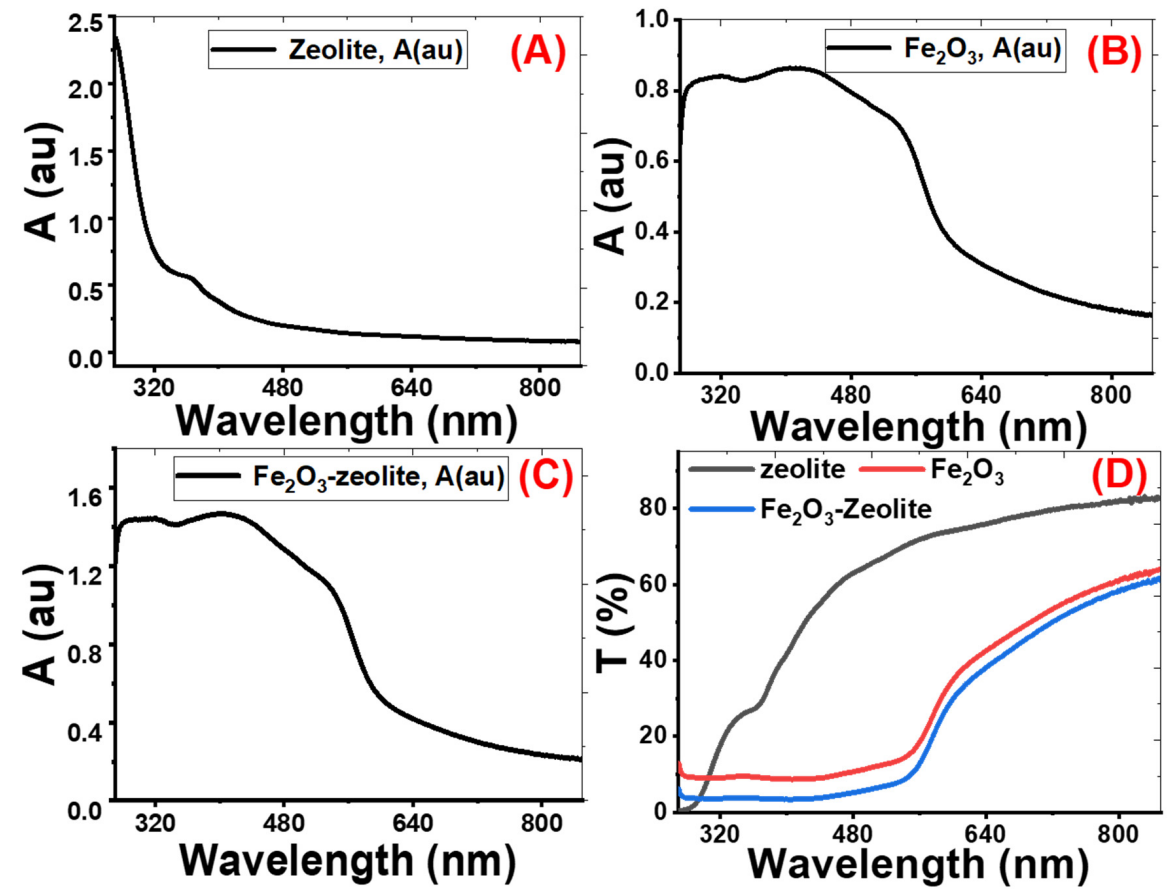

Figure 5. Absorbance ( $\mathrm{A} \%$ ) for zeolite $(\mathbf{A}), \mathrm{Fe}_{2} \mathrm{O}_{3}(\mathbf{B})$, and $\mathrm{Fe}_{2} \mathrm{O}_{3} /$ zeolite $(\mathbf{C})$, and transmittance (T\%) for all samples (D).

The absorbance spectra for $\mathrm{Fe}_{2} \mathrm{O}_{3}$ and $\mathrm{Fe}_{2} \mathrm{O}_{3}$ / zeolite show similar optical behaviors, as seen in Figure 5B,C. The $\mathrm{Fe}_{2} \mathrm{O}_{3}$ has strong photoabsorption in the UV and visible spectral regions [35]. $\mathrm{Fe}_{2} \mathrm{O}_{3}$ shows an absorption band edges up to $580 \mathrm{~nm}$. The wide absorption band of $\mathrm{Fe}_{2} \mathrm{O}_{3}$ in the visible region is due to the direct transition $\left(\mathrm{O}^{2-} 2 \mathrm{p} \rightarrow \mathrm{Fe}^{3+} 3 \mathrm{~d}\right)$ and the spin-forbidden-excitations $\left(\mathrm{Fe}^{3+} 3 \mathrm{~d} \rightarrow 3 \mathrm{~d}\right)$, which rises the indirect transitions [36-38].

For the $\mathrm{Fe}_{2} \mathrm{O}_{3}$ /zeolite, Figure 5C, the right edge of the photons uptake band shifts to a longer $\lambda$ compared with that of $\mathrm{Fe}_{2} \mathrm{O}_{3}$, Figure 5B. This is correlated with the size of the nanoparticles of the $\mathrm{Fe}_{2} \mathrm{O}_{3}$ formed in the zeolite matrix. Hence, a broad and intense visible absorption range was observed for the $\mathrm{Fe}_{2} \mathrm{O}_{3}$ /zeolite in Figure 5B. This would be better to achieve a massive electron-hole pair generation through electron transportation between the valence and conduction bands.

The absorbance values at $\lambda=500 \mathrm{~nm}$ are $0.185,0.765$ and 1.219 for zeolite, $\mathrm{Fe}_{2} \mathrm{O}_{3}$, and $\mathrm{Fe}_{2} \mathrm{O}_{3}$ /zeolite, respectively, as seen in Figure 5D. This means more photons in the visible region, the concentrated portion of the solar light, can be absorbed by $\mathrm{Fe}_{2} \mathrm{O}_{3} /$ zeolite than $\mathrm{Fe}_{2} \mathrm{O}_{3}$. This high absorbance refers to the dispersion of the $\mathrm{Fe}_{2} \mathrm{O}_{3}$ aggregates within the zeolite mesoporous structure and the modification of the electronic structure of $\mathrm{Fe}_{2} \mathrm{O}_{3}$ /zeolite. Hence, zeolite has effectively enhanced the visible light absorption capability of the loaded $\mathrm{Fe}_{2} \mathrm{O}_{3}$ nanostructures. From Figure 5D, the general behavior of the transmittance spectrum of zeolite is the increase of transmittance\% with the wavelength from UV to the visible region. The low transmittance for zeolite in the UV region is due to the existence of a strong absorption band in this region. The transmittance spectra for $\mathrm{Fe}_{2} \mathrm{O}_{3}$ and $\mathrm{Fe}_{2} \mathrm{O}_{3}$ / zeolite (Figure 5D) can be divided into two regions. At wavelengths from 250 to $550 \mathrm{~nm}$, the transmittance is nearly constant below $12 \%$. Above $550 \mathrm{~nm}$, the transmittance of $\mathrm{Fe}_{2} \mathrm{O}_{3}$ and $\mathrm{Fe}_{2} \mathrm{O}_{3}$ /zeolite varies linearly with wavelength. The transmission of $\mathrm{Fe}_{2} \mathrm{O}_{3} /$ zeolite is higher than that of $\mathrm{Fe}_{2} \mathrm{O}_{3}$ in the whole range of wavelengths.

The diffuse reflectance spectra (DRS) of the photocatalysts were measured to estimate the bandgap energies of the $\mathrm{Fe}_{2} \mathrm{O}_{3}$ and $\mathrm{Fe}_{2} \mathrm{O}_{3}$ /zeolite. For this purpose, the KubelkaMunk (K-M) model was used. Based on the following equation, this approach allows 
the absorption coefficient to be calculated by measuring diffuse light reflectance from a powdered mixture comprising absorbing and scattering components [39].

$$
\mathrm{F}(\mathrm{R})=(1-\mathrm{R})^{2} / 2 \mathrm{R}=\alpha / \mathrm{S}
$$

where $\mathrm{F}(\mathrm{R}), \mathrm{R}, \mathrm{S}$, and $\alpha$ indicate the $\mathrm{K}-\mathrm{M}$ function, diffuse reflectance of the sample, the scattering coefficient, and the absorption coefficient, respectively. The $\mathrm{K}-\mathrm{M}$ function is directly proportional to the absorption coefficient. Therefore, the direct and/or indirect band gaps of $\mathrm{Fe}_{2} \mathrm{O}_{3}$ and $\mathrm{Fe}_{2} \mathrm{O}_{3}$ / zeolite were estimated by the following equation

$$
\left(\alpha \mathrm{E}_{\mathrm{p}}\right)^{\mathrm{n}}=G(\mathrm{~h} v-\mathrm{Eg})
$$

where $E_{p}, E g$, and $G$ refer to the photon energy, bandgap energy, and independent constant. For indirect bandgaps, $\mathrm{n}=1 / 2$, while for direct bandgaps, $\mathrm{n}=2$ [40]. The absorption bandgaps energies (direct or indirect) can be calculated from the straight-line portions of $\left(\alpha E_{p}\right)^{n}$ versus $E_{p}$ curve that intersects the energy axis, as shown in Figure 6.
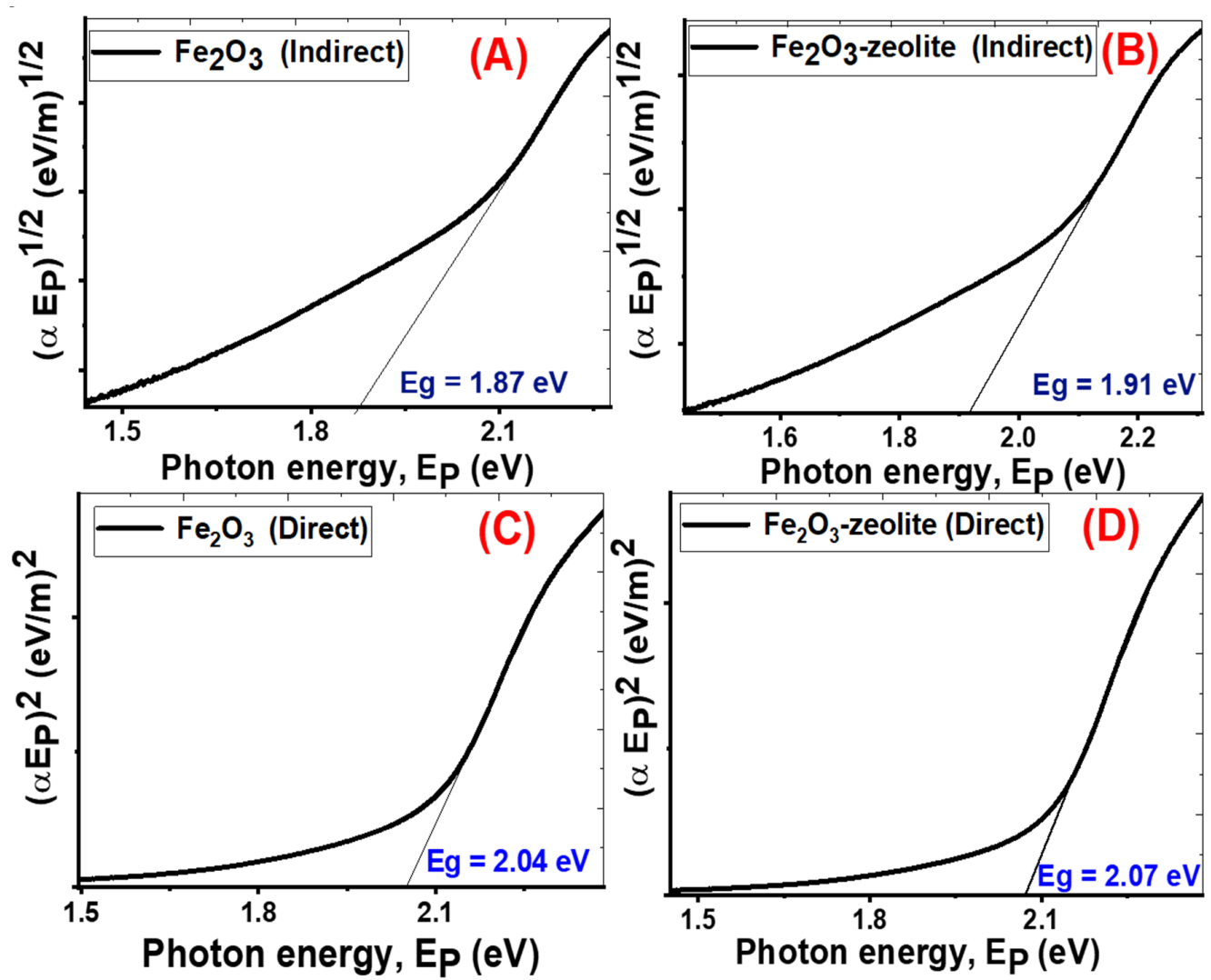

Figure 6. Indirect energy gap $(\mathbf{A}, \mathbf{B})$ for $\mathrm{Fe}_{2} \mathrm{O}_{3}$, and $\mathrm{Fe}_{2} \mathrm{O}_{3} /$ zeolite and direct energy gap $(\mathbf{C}, \mathbf{D})$ for $\mathrm{Fe}_{2} \mathrm{O}_{3}$, and $\mathrm{Fe}_{2} \mathrm{O}_{3} /$ zeolite, respectively.

The $\mathrm{Fe}_{2} \mathrm{O}_{3}$ and $\mathrm{Fe}_{2} \mathrm{O}_{3} /$ zeolite have indirect bandgap values of 1.87 and $1.91 \mathrm{eV}$ and direct bandgap values of 2.04 and $2.07 \mathrm{eV}$, respectively (Figure 6), which demonstrates the formation and incorporation of $\mathrm{Fe}_{2} \mathrm{O}_{3}$ nanoparticles in the zeolite. These values are consistent with the reported values for $\mathrm{Fe}_{2} \mathrm{O}_{3}$ prepared by different techniques in the [22,41]. Based on the quantization effect, the bandgap is proportional inversely to the crystallite size due to the confinement of the movement of electrons. Therefore, the increase in the bandgap of $\mathrm{Fe}_{2} \mathrm{O}_{3}$ /zeolite compared to $\mathrm{Fe}_{2} \mathrm{O}_{3}$ can be understood based on the decrease in the crystallite size as seen in XRD data. This behavior is similar to that reported for many nanomaterials such as $\mathrm{ZnO}$ and ITO [42,43]. The studied optical properties suggest that the produced $\mathrm{Fe}_{2} \mathrm{O}_{3}$ from the rusted iron and its loading on zeolite as a host can greatly 
improve its semiconducting performance toward the massive absorption of the visible light. This suggests that the prepared $\mathrm{Fe}_{2} \mathrm{O}_{3}$ / zeolite can be used for solar energy applications.

\subsubsection{FT-IR Study}

FT-IR data of $\mathrm{Fe}_{2} \mathrm{O}_{3}$, zeolite and $\mathrm{Fe}_{2} \mathrm{O}_{3}$ /zeolite nanocomposite are shown in Figure S1 (Supplementary Materials). The FT-IR spectrum of $\mathrm{Fe}_{2} \mathrm{O}_{3}$ nanoparticles was observed in the $4000-400 \mathrm{~cm}^{-1}$ wavenumber range, Figure S1. The bands of $\mathrm{Fe}_{2} \mathrm{O}_{3}$ appear at 1641 and $3415 \mathrm{~cm}^{-1}$, owing to the bending vibrations of the absorbed $\mathrm{H}_{2} \mathrm{O}$ and surface hydroxyl, and $\mathrm{O}-\mathrm{H}$ stretch modes [20]. The appeared absorption modes at 2920 and $2850 \mathrm{~cm}^{-1}$ are assigned to the symmetric and asymmetric $-\mathrm{CH}_{2}{ }^{-}$groups stretch modes. A strong $\mathrm{Fe}-\mathrm{O}$ asymmetric stretching mode was detected around $1040 \mathrm{~cm}^{-1}$ [44]. The located bands at 461,537 , and $790 \mathrm{~cm}^{-1}$ were attributed to the $\mathrm{Fe}-\mathrm{O}$ stretch mode of $\mathrm{Fe}_{2} \mathrm{O}_{3}$ as confirmed in the literature [45]. A strong $\mathrm{Fe}-\mathrm{O}$ asymmetric stretching mode was detected around $1040 \mathrm{~cm}^{-1}$ [44]. The located bands at 461, 537, and $790 \mathrm{~cm}^{-1}$ were attributed to the $\mathrm{Fe}-\mathrm{O}$ stretch mode of $\mathrm{Fe}_{2} \mathrm{O}_{3}$ [45]. For zeolite, the bands at 3620 and $3446 \mathrm{~cm}^{-1}$ were attributable to $\mathrm{Si}-\mathrm{OH}$ groups with $\mathrm{H}$-bonding. The absorption mode at $1640 \mathrm{~cm}^{-1}$ was attributed to the $\mathrm{OH}$ bending mode [46]. The strong 1040, 790, and $600 \mathrm{~cm}^{-1}$ modes were significant to the internal asymmetric stretch and external symmetric stretch of $\mathrm{X}-\mathrm{O}-\mathrm{X}(\mathrm{X}=\mathrm{Al}$ or $\mathrm{Si}$ ), and the internal $\mathrm{X}-\mathrm{O}$ bending mode of $\mathrm{AlO}_{4} / \mathrm{SiO}_{4}$ tetrahedral [46]. The modes at 600 and $470 \mathrm{~cm}^{-1}$ authorize the existence of double five-membered rings of the pentasil zeolite [46]. For $\mathrm{Fe}_{2} \mathrm{O}_{3}$ /zeolite, there are mixed bands between $\mathrm{Fe}_{2} \mathrm{O}_{3}$ and zeolite. The presence of broadband at $3429 \mathrm{~cm}^{-1}$ can be certified the $\mathrm{O}-\mathrm{H}$ stretch mode, while the mode at $1650 \mathrm{~cm}^{-1}$ can be referred to as the $\mathrm{O}-\mathrm{H}$ bending [47]. Bands of the zeolite appear at $1000 \mathrm{~cm}^{-1}$ in the nanocomposite, and the shift of these bands relative to that of zeolite refers to the break of $\mathrm{H}$-bonds as a result of the existence of $\mathrm{Fe}$ on zeolite $\mathrm{SiO}_{4} / \mathrm{AlO}_{4}$ surfaces. Strong bands at 720,598,530, and $460 \mathrm{~cm}^{-1}$ were attributed to the symmetric vibration of ( $\mathrm{Al}$ or $\mathrm{Si})-\mathrm{O}$ due to the internal vibration of zeolite.

\subsection{Photoelectrocatalytic (PEC) $\mathrm{H}_{2}$ Generation}

\subsubsection{PEC Characteristics and Conversion Efficiencies}

PEC technology for converting solar energy to hydrogen via the water-splitting cycle was aided by the catalysts $\mathrm{Fe}_{2} \mathrm{O}_{3}$ and $\mathrm{Fe}_{2} \mathrm{O}_{3}$ / zeolite. When $\mathrm{Fe}_{2} \mathrm{O}_{3}$ is subjected to light, the electron $\left(\mathrm{e}^{-}\right)$can be excited from the valence band, leaving a hole $\left(\mathrm{h}^{+}\right)$to the conduction band. The rate of hydrogen production depends on the lifetime of the carrier charge. The limitations of bare $\alpha-\mathrm{Fe}_{2} \mathrm{O}_{3}$ faces in use as a PEC photoanode arise from the electronic structure of the material. The $\alpha-\mathrm{Fe}_{2} \mathrm{O}_{3}$ suffers from a high density of mid bandgap trap states arising from closely spaced $\mathrm{d}$ levels that result in closely spaced optical transitions spanning the visible and into the near-ultraviolet regions. This leads to low carriers' mobility and short lifetimes. In the $\mathrm{Fe}_{2} \mathrm{O}_{3}$ /zeolite nanocomposite, the electrons can be trapped on the surface of the mesoporous zeolite. The zeolitic network can inhibit recombination of e/h pairs due to strong electric field strength through the distribution of photogenerated electrons inside zeolite [48]. Hence, the effective $\mathrm{e}^{-} / \mathrm{h}^{+}$separation occur over robust interfacial interactions in $\mathrm{Fe}_{2} \mathrm{O}_{3} /$ zeolite. This causes a decrease in $\mathrm{e}^{-} / \mathrm{h}^{+}$recombination rates, which results in an efficient photoelectrocatalytic performance of $\mathrm{Fe}_{2} \mathrm{O}_{3}$-zeolite. Additionally, the $\mathrm{Fe}_{2} \mathrm{O}_{3}$ /zeolite has a large effective surface area due to the porous framework of zeolite, which can increase PEC efficiency and allow for more intense absorption of incident light.

The optimized content of $\mathrm{Fe}_{2} \mathrm{O}_{3}$ and zeolite is highly desirable to reach high PEC performance. The photocurrent density is measured for $\mathrm{Fe}_{2} \mathrm{O}_{3}$ (III), $\mathrm{Fe}_{2} \mathrm{O}_{3}$ (II), and $\mathrm{Fe}_{2} \mathrm{O}_{3}$ (I) at an applied voltage of $1 \mathrm{~V}$ in $0.9 \mathrm{M} \mathrm{KOH}$ under light illumination, as seen in Figure S2 (Supplementary Materials). The photocurrent density is found to be 57.5, 48.82, and $42.64 \mathrm{~mA} / \mathrm{cm}^{2} \mathrm{Fe}_{2} \mathrm{O}_{3}$ (III), $\mathrm{Fe}_{2} \mathrm{O}_{3}$ (II), and $\mathrm{Fe}_{2} \mathrm{O}_{3}$ (I), respectively. Therefore, $\mathrm{Fe}_{2} \mathrm{O}_{3}$ (III) photoelectrode produces the highest photocurrent, which considers the optimized PEC photoelectrode. Additionally, nanocomposites of varied $\mathrm{Fe}_{2} \mathrm{O}_{3}$ (III)/zeolite weight ratios $(0.2 / 1.8,0.6 / 1.4,0.8 / 1.2,1.0 / 1.0,1.2 / 0.8,1.4 / 0.6$, and 1.8/0.2) are utilized to manufacture 
$\mathrm{Fe}_{2} \mathrm{O}_{3}$ /zeolite photoelectrodes for hydrogen production in order to optimize the nanocomposite composition. The photocurrent densities for all electrodes are measured under light illumination and at $1 \mathrm{~V}$, as seen in Figure S3 (Supplementary Materials). The highest photocurrent density is found to be $57.93 \mathrm{~mA} / \mathrm{cm}^{2}$ for $\mathrm{Fe}_{2} \mathrm{O}_{3} /$ zeolite with a weight ratio of $1: 1$.

Figure 7 shows the PEC performance of the optimized electrode. The variation of the current density $(\mathrm{J})$ in darkness and white lighting from a metal-halide lamp versus the applied voltage (E) is presented in Figure $7 \mathrm{~A}$ at $25^{\circ} \mathrm{C}$ with a sweep rate of $0.1 \mathrm{mV} / \mathrm{s}$. Using the $\mathrm{Fe}_{2} \mathrm{O}_{3}$ and $\mathrm{Fe}_{2} \mathrm{O}_{3}$ /zeolite photo-electrocatalysts and in white lighting, the value of $\mathrm{J}$ is greatly enhanced vs. the positive applied voltage. By switching from the dark status to white light illumination status, the current density of $\mathrm{Fe}_{2} \mathrm{O}_{3}$ is increased from 1.14 to $29.1 \mathrm{~mA} / \mathrm{cm}^{2}$ at $+1 \mathrm{~V}$, which refers to the PEC effect of $\mathrm{Fe}_{2} \mathrm{O}_{3}$. As shown in Figure 7A, $\mathrm{J}$ is increased by loading $\mathrm{Fe}_{2} \mathrm{O}_{3}$ on zeolite from 29.1 to $57.6 \mathrm{~mA} / \mathrm{cm}^{2}$ at $+1 \mathrm{~V}$. This is due to the extending of the bandgap to the Vis/NIR range, which speeds up the redox reactions and then facilitates the PEC reaction. This also suggests a $\sim 2$-fold enhancement of the J-value relative to the $\mathrm{Fe}_{2} \mathrm{O}_{3}$ photocatalyst, which agrees with the increase of the surface charge, the extension of $\mathrm{E}_{\mathrm{g}}$, and the strong absorptions in the Vis/NIR because of the loading of $\mathrm{Fe}_{2} \mathrm{O}_{3}$. In addition, it is very well-associated with the size variation of the $\mathrm{Fe}_{2} \mathrm{O}_{3}$ nanoparticles. Reduction in the size of $\mathrm{Fe}_{2} \mathrm{O}_{3}$ nanoparticles after loading on zeolite compared to $\mathrm{Fe}_{2} \mathrm{O}_{3}$ nanopowder, Figure 3, leads to greater surface areas and enhanced active surface spots that improve hydrogen generation activity. Additionally, $\mathrm{Fe}_{2} \mathrm{O}_{3}$ /zeolite's quantum confinement raises the reduction potentials to transfer the bound protons to $\mathrm{H}_{2}$ molecules. The quantum containment of $\mathrm{Fe}_{2} \mathrm{O}_{3}$ / zeolite allows for further effective absorption in the Vis/NIR region (Figure 5). Note that $\mathrm{Fe}_{2} \mathrm{O}_{3}$ and $\mathrm{Fe}_{2} \mathrm{O}_{3}$ /zeolite photoelectrocatalysts exhibit light-harvesting with J-values of 0.58 and $1.01 \mathrm{~mA} / \mathrm{cm}^{2}$ at $0 \mathrm{~V}$, and photocurrent onset at -0.098 and $-0.056 \mathrm{~V}$, correspondingly. It shows that, after loading $\mathrm{Fe}_{2} \mathrm{O}_{3}$ on the zeolite matrix, the interfacial transport resistances decrease, emphasizing the importance of the loading process in improving PEC efficiency. As a result of ions' exchange ability, vacant sites in the zeolite surface also photoassisted hydrogen production [49]. Simultaneously, zeolite's aluminosilicate frame is contributing to delayed charge carriers' separations [50]. Since the control processes of electron/hole transfer are very important in photocatalytic reactions, zeolite can play an active role in electron transfer processes as an electron acceptor or electron donor. [51,52]. The Z-scheme mechanism for the nanocomposite can maintain photogenerated charge carriers with strong redox ability. The spatial isolation of charge carriers is providing a large driving force for the photocatalytic water reduction reaction [53]. To assess the photoelectrocatalysts performances as a tiny outer voltage is introduced between the electrodes of the PEC cell, the electrical energies introduced to the cell have to be deducted. This may be accomplished using the applied bias photon to current conversion efficiency (ABPE). The following Equation (3) is used to compute ABPE [54]:

$$
\operatorname{ABPE}(\%)=J \frac{\left(1.23-E_{\text {app }}\right)}{p} \times 100
$$

where $E_{a p p}$ is the externally applied bias and $p$ refers to the illuminating light power density $\left(75 \mathrm{~mW} / \mathrm{cm}^{2}\right)$. Figure 7B demonstrates how ABPE varies with applied voltage at various wavelengths. The two highest $\mathrm{ABPE} \%$ values are de-convoluted under white light illumination; $(3.37 \%$ at $0.464 \mathrm{~V}$ and at $8.78 \%$ at $0.997 \mathrm{~V})$ for $\mathrm{Fe}_{2} \mathrm{O}_{3}$ and $(12.05 \%$ at $0.430 \mathrm{~V}$ and $20.01 \%$ at $0.882 \mathrm{~V}$ ) for $\mathrm{Fe}_{2} \mathrm{O}_{3}$ /zeolite. This indicates a $\sim$-fold improvement along with a decrease of the applied voltage, which can be beneficial for PEC cell operation. Additionally, $\mathrm{Fe}_{2} \mathrm{O}_{3}$ /zeolite photocatalyst displays $\mathrm{ABPE} \%$ of $1.64 \%$ at $0 \mathrm{~V}$. This demonstrates that interfacial transport resistances have been reduced and photocatalytic performance has improved [54]. 

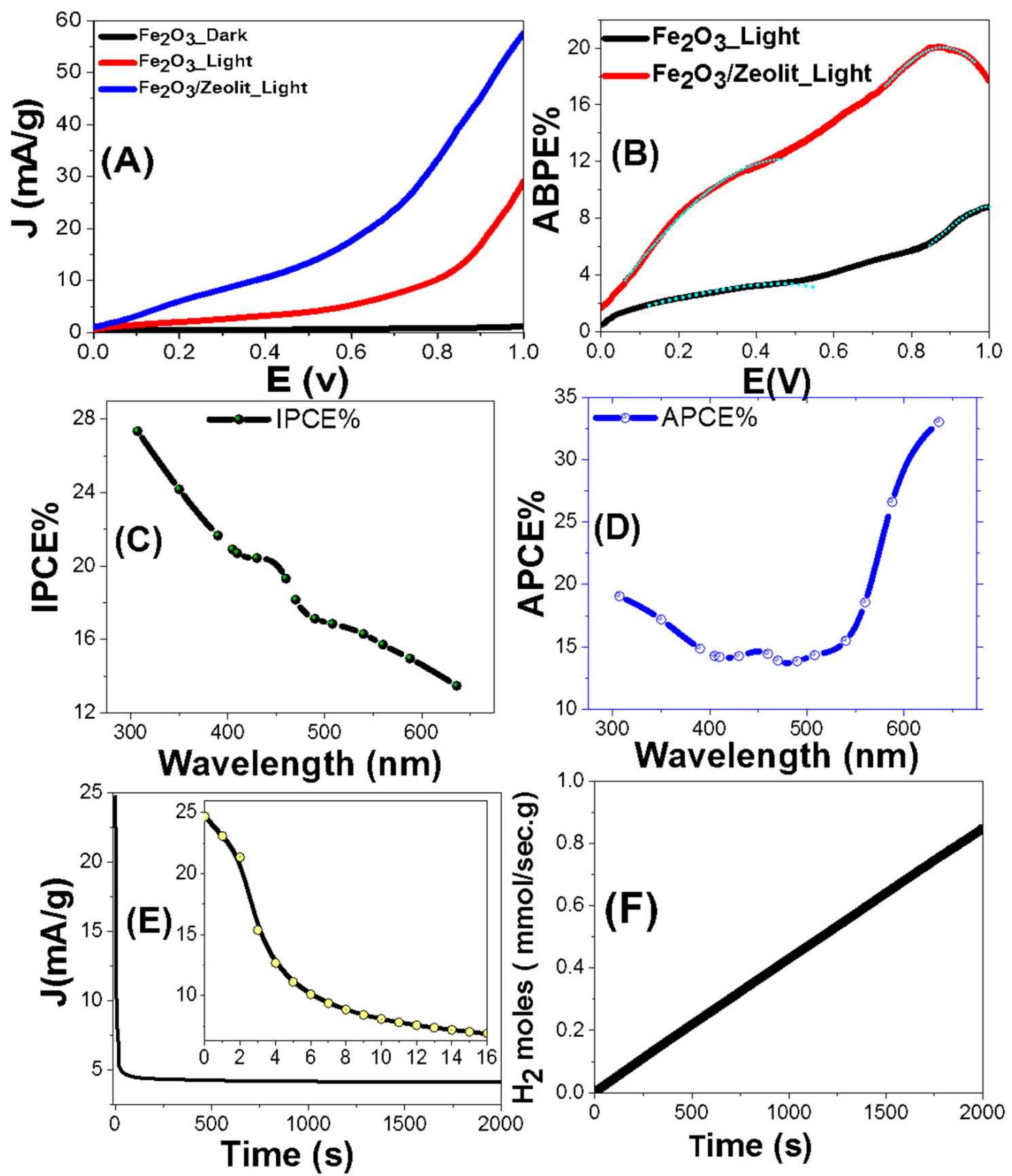

Figure 7. (A) The current density (J) vs. the applied potential for $\mathrm{Fe}_{2} \mathrm{O}_{3}$ and $\mathrm{Fe}_{2} \mathrm{O}_{3}$ / zeolite under darkness and white light exposure, (B) APBE\%, (C) IPCE\% $(\lambda)$, and (D) APCE\% $(\lambda) @ 1 \mathrm{~V}$ vs. the incident wavelengths; variation of $(\mathrm{E}) \mathrm{J}$ and $(\mathrm{F})$ the number of $\mathrm{H}_{2}$ moles versus the exposure time.

The enhanced solar absorption of the $\mathrm{Fe}_{2} \mathrm{O}_{3}$ /zeolite photocatalyst is verified by estimating the photon-to-current incident efficiency (IPCE) at various wavelengths $(\lambda)$ of the incident photons and constant potential $(+1 \mathrm{~V})$. The IPCE is calculated using the following Equation (4) [40]:

$$
\mathrm{IPCE} \%=1240 \cdot \frac{\mathrm{J}}{\lambda . \mathrm{P}} 100
$$

where $\lambda$ is in nm. The variation of IPCE\% with the wavelength of the monochromatic light for $\mathrm{Fe}_{2} \mathrm{O}_{3} /$ zeolite photocatalyst is represented in Figure 7C. The highest IPCE\% is $\sim 27.34 \%$ $@ 307 \mathrm{~nm}$, in addition to another peak of $20.37 \%$ centered at $\sim 440 \mathrm{~nm}$ corresponding to the highest absorption seen in Figure 5. 
In the IPCE calculations, optical losses including transmittance (T) or reflectance (R) of incident photons were neglected. To compensate the optical losses, the absorbed photon to current conversion efficiency (APCE) is measured. APCE represents the number of photogenerated carriers that participate per absorbed photon in the generated photocurrent. The APCE is computed using the following Equation (5) [55]:

$$
\operatorname{APCE}(\lambda)=\frac{\operatorname{IPCE}(\lambda)}{\mathrm{A}(\lambda)}=\frac{\operatorname{IPCE}(\lambda)}{1-\mathrm{R}-\mathrm{T}}
$$

Here, A represents the optical absorbance. Figure 7D displays the behavior of APCE\% as a function of the wavelength. As noted, APCE\% is 19.1\%@307 nm; then, it decreases to reach $13.8 \% @ 490 \mathrm{~nm}$, followed by a successive increase to reach a maximum value of $33.0 \% @ 636 \mathrm{~nm}$.

The stability of the $\mathrm{Fe}_{2} \mathrm{O}_{3}$ /zeolite photocatalyst, for $\mathrm{H}_{2}$ generation, is studied for a prolonged time in $0.9 \mathrm{M} \mathrm{KOH}$ under white light and an applied voltage of $+1 \mathrm{~V}$ Figure 7E shows the evolution of the J throughout time. The J-value dropped dramatically within the first $16 \mathrm{~s}$, reaching roughly $6.9 \mathrm{~mA} / \mathrm{g}$. Then, limited photocorrosion processes occur between the PEC catalyst and the redox electrolyte, which account for the dramatic fall in the J-value [3]. For time $>16 \mathrm{~s}$, before achieving a steady value of roughly $4.63 \mathrm{~mA} / \mathrm{g}$ for $60 \mathrm{~s}$, there is a slight reduction in J-value. This demonstrates that, in spite of the early decline in J-value, the $\mathrm{Fe}_{2} \mathrm{O}_{3}$ /zeolite photocatalyst has high photochemical stability and a

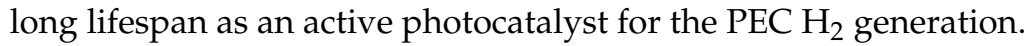

The full amount of hydrogen energy generated to the overall input sunlight energy (AM 1.5 G, $100 \mathrm{~mW} / \mathrm{cm}^{2}$ ) is the solar-to-hydrogen conversion efficiency (STH). It can be used to calculate the total efficiency of the PEC cell [56]:

$$
\mathrm{STH}=\left[\left(\mathrm{mmol} \mathrm{H}_{2} / \mathrm{s}\right) \times(237 \mathrm{KJ} / \mathrm{mol})\right] /\left[\mathrm{P}_{\text {total }} \times \mathrm{ECSA}\right]
$$

where $\mathrm{P}_{\text {total }}, \mathrm{ECSA}$, and $\mathrm{H}_{2} / \mathrm{S}$ refer to the total light power density in $\mathrm{mW} \mathrm{cm}^{-2}$, the electrochemical surface area in $\mathrm{cm}^{2}$, and the rate of hydrogen generation/s, respectively. Applying Faraday's law, the number of generated $\mathrm{H}_{2}$ moles by the PEC cell can be calculated using Equation (7).

$$
\mathrm{H}_{2} \text { (moles) }=\int_{0}^{\mathrm{t}} \frac{\mathrm{Jdt}}{\mathrm{F}}
$$

Here, $\mathrm{F}$ refers to the Faraday constant $\left(9.65 \times 10^{4} \mathrm{C} / \mathrm{mol}\right)$, and $\mathrm{t}$ is the period of generation. Figure 7F shows the variation of $\mathrm{H}_{2}$ (moles) versus the production time. The creation rate of $\mathrm{H}_{2}$ is $154.44 \mathrm{mmol} \mathrm{h}^{-1} \mathrm{~g}^{-1}$. Zeolite plays an effective role in the rapid spread of hydrogen bubbles which escape from the photocatalyst. This paves the way for higher current and additional $\mathrm{H}_{2}$ creation over the same period [57].

The ECSA of $\mathrm{Fe}_{2} \mathrm{O}_{3}$ and $\mathrm{Fe}_{2} \mathrm{O}_{3}$ /zeolite photocatalysts were obtained utilizing the Randles-Sevcik equation,

$$
\mathrm{ECSA}=\mathrm{I}(\mathrm{RT})^{0.5}(\mathrm{C} n \mathrm{~F})^{-1.5}(v \mathrm{D})^{-0.5} / 0.4463
$$

Here, $n, C$, and $T$ stand for the number of electrons in a redox reaction $(n=1)$, analyte concentration, and temperature, correspondingly, while F, R, and D stand for Faraday, gasmolar, and analyte diffusion constants [26]. Utilizing Figure 7A, the ECSAs of the photocatalysts were found using ECSA $=\mathrm{Q} \cdot \mathrm{m}^{-1} / \mathrm{C}$, whereas $\mathrm{Q}, \mathrm{m}$, and $\mathrm{C}$ indicate the negative-scan hydrogen-adsorption charges after double-layer charge modification, photocatalyst mass, and complete monolayer charges of the electrode-cover $\mathrm{H}$-atoms, respectively [26]. The $\mathrm{Q}$ value was estimated by integrating the curve of the photocatalyst, Figure 7A, divided by the scan rate. The values of ECSA for the photocatalysts are determined and presented in Table 3. For $\mathrm{Fe}_{2} \mathrm{O}_{3}$ and $\mathrm{Fe}_{2} \mathrm{O}_{3}$ /zeolite, the values were 7.414 and $21.236 \mathrm{~m}^{2} / \mathrm{g}$, respectively. The 3-fold improvement in the ECSA explains the improved PEC performance, Figure 7A, 
of $\mathrm{Fe}_{2} \mathrm{O}_{3}$ /zeolite photocatalyst versus the $\mathrm{Fe}_{2} \mathrm{O}_{3}$. Then, the estimated $\mathrm{STH}$ value was $12.74 \%$ for the $\mathrm{Fe}_{2} \mathrm{O}_{3}$ / zeolite photocatalyst.

Table 3. ECSA values and corrosion and Tafel parameters for $\mathrm{Fe}_{2} \mathrm{O}_{3}$ and $\mathrm{Fe}_{2} \mathrm{O}_{3} /$ zeolite photocatalysts.

\begin{tabular}{|c|c|c|c|c|c|c|c|c|c|}
\hline Sample & $\begin{array}{l}\text { ECSA } \\
\left(\mathrm{m}^{2} / \mathrm{g}\right)\end{array}$ & $\begin{array}{l}\mathrm{E}_{\text {Corr }} \\
(\mathrm{mVV})\end{array}$ & $\begin{array}{c}\mathrm{I}_{\mathrm{Corr}} \\
\left(\mu \mathrm{A} \mathrm{cm}^{-2}\right)\end{array}$ & $\begin{array}{c}\beta_{\mathrm{a}} \\
\left(\mathrm{mV} \mathrm{dec}^{-1}\right)\end{array}$ & $\mathbf{R}^{2}$ & $\begin{array}{c}\beta_{\mathrm{c}} \\
\left(\mathrm{mV} \mathrm{dec}^{-1}\right)\end{array}$ & $\mathbf{R}^{2}$ & $\begin{array}{c}\mathrm{R}_{\mathrm{p}} \\
\left(\Omega \mathrm{cm}^{2}\right)\end{array}$ & $\begin{array}{c}\text { Corr Rate } \\
\left(\mathrm{nm}_{\text {year }}^{-1}\right)\end{array}$ \\
\hline $\mathrm{Fe}_{2} \mathrm{O}_{3}$ & 7.414 & 478.28 & 3.15 & $63.4 \pm 0.9$ & 0.996 & $6.8 \pm 0.2$ & 0.988 & 847.66 & 0.01502 \\
\hline $\mathrm{Fe}_{2} \mathrm{O}_{3} /$ zeolite & 21.236 & 376.72 & 2.66 & $139.9 \pm 2.8$ & 0.992 & $5.5 \pm 0.1$ & 0.989 & 864.98 & 0.00761 \\
\hline
\end{tabular}

\subsubsection{Corrosion and Tafel Parameters of $\mathrm{Fe}_{2} \mathrm{O}_{3}$ and $\mathrm{Fe}_{2} \mathrm{O}_{3}$ /Zeolite Photocatalysts}

The Tafel relationship, $\mathrm{V}=\beta \log (\mathrm{J})+\mathrm{C}$, was used to quantify combined anodic and cathodic Tafel or polarization parameters to determine the mechanism of the $\mathrm{H}_{2}$ generation reaction(HGR) and the rate-limiting phase [58]. Low Tafel slopes, high current exchange rates, and good HGR performances are all characteristics of the ideal photocatalyst. Figure 8A shows the Tafel plots for $\mathrm{Fe}_{2} \mathrm{O}_{3}$ and $\mathrm{Fe}_{2} \mathrm{O}_{3}$ /zeolite. Figure 8B,C displays the main characteristics: corrosion potential and current $\left(\mathrm{E}_{\text {corr }}\right.$ and $\left.\mathrm{I}_{\text {corr }}\right)$ and anodic $\left(\beta_{\mathrm{a}}\right)$ and cathodic $\left(\beta_{\mathrm{c}}\right)$ Tafel slopes for the $\mathrm{Fe}_{2} \mathrm{O}_{3}$ and $\mathrm{Fe}_{2} \mathrm{O}_{3} /$ zeolite. The values of $\beta_{\mathrm{a}}$ and $\beta_{\mathrm{c}}$ for $\mathrm{Fe}_{2} \mathrm{O}_{3}$ and $\mathrm{Fe}_{2} \mathrm{O}_{3}$ /zeolite are found using the slopes of the curves' linear segments, as shown in Figure $8 \mathrm{D}, \mathrm{E}[26,59]$. The obtained values of $\mathrm{E}_{\mathrm{corr}}, \mathrm{I}_{\mathrm{corr}}, \beta_{\mathrm{a}}$, and $\beta_{\mathrm{c}}$ were presented in Table 3 for $\mathrm{Fe}_{2} \mathrm{O}_{3}$ and $\mathrm{Fe}_{2} \mathrm{O}_{3}$ /zeolite. For $\mathrm{Fe}_{2} \mathrm{O}_{3} /$ zeolite, the $\beta_{\mathrm{a}}$ and $\beta_{\mathrm{c}}$ values are 139.9 and $5.5 \mathrm{mV} \mathrm{dec}^{-1}$, respectively, and 63.4 and $6.8 \mathrm{mV} \mathrm{dec}^{-1}$ for $\mathrm{Fe}_{2} \mathrm{O}_{3}$. The PEC HGR mechanism and rate-limiting phases are indicated by the Tafel slopes. The Volmer-Tafel mechanism is predominant when the recombination phase is a rate limit and the Tafel slope is $30 \mathrm{mV} \mathrm{dec}^{-1}$. The Volmer-Heyrovsky $\mathrm{H}_{2}$ generation process could be presumed to be dominant when PEC desorption is a rate limit and the Tafel slope is $40 \mathrm{mV} \mathrm{dec}{ }^{-1}$. The reaction pathways are dependent on the surfaces covered with adsorbed hydrogen if the Tafel slope is $120 \mathrm{mV} \mathrm{dec}{ }^{-1}$. The $\beta_{\mathrm{c}}$-value denotes the needed over-potential to enhance the HGR rate by a factor of ten $[26,59]$. The low values of $\beta c$ refer to the low optical band gaps of the designed $\mathrm{Fe}_{2} \mathrm{O}_{3}$ and $\mathrm{Fe}_{2} \mathrm{O}_{3}$ /zeolite photocatalysts. This means that small amounts of energy (low overpotentials) are needed to achieve efficient HGR.

The corrosion rate is directly dependent on $\mathrm{I}_{\text {corr }}$, where $\mathrm{E}_{\text {corr }}$ offers aspects about the solution's corrosion propensity. From Figure $8 \mathrm{~A}-\mathrm{C}$, the $\mathrm{Fe}_{2} \mathrm{O}_{3}$ /zeolite presents nobler behavior. The $\mathrm{Fe}_{2} \mathrm{O}_{3} /$ zeolite has a smaller $\mathrm{E}_{\text {corr }}(376.7 \mathrm{mV})$ than $\mathrm{Fe}_{2} \mathrm{O}_{3}(478.3 \mathrm{mV})$. Generally, the $\mathrm{E}_{\text {corr }}$ values revealed in this work are greater than any earlier stated values for $\mathrm{Fe}_{2} \mathrm{O}_{3}$-based photocatalysts and are moved to more noble behaviors when compared to commercial $\mathrm{Fe}_{2} \mathrm{O}_{3}$ [60].

To verify the relative ability of the electrode to resist corrosions; the values of $\mathrm{I}_{\mathrm{corr}}$, polarization resistance $\left(R_{P}\right)$, and corrosion rate $(C R)$ could be determined. The $C R$ is related to the kinetic value $\mathrm{I}_{\text {corr }}$ directly, while $\mathrm{R}_{\mathrm{p}}$ is inversely proportional. From Table 2, the loading of $\mathrm{Fe}_{2} \mathrm{O}_{3}$ on the zeolite host reduces $\mathrm{I}_{\text {corr }}$ from 3.15 to $2.66 \mu \mathrm{A} \mathrm{cm}^{-2}$, which is much smaller than any previously reported $\mathrm{Fe}_{2} \mathrm{O}_{3}$ photoelectrode's corrosion current. For example, Kim et al. reported $5.31 \mu \mathrm{A} / \mathrm{cm}^{2}$ for $\mathrm{Fe}_{2} \mathrm{O}_{3}$ and $8.69 \mu \mathrm{A} / \mathrm{cm}^{2}$ for $\mathrm{Fe}_{3} \mathrm{O}_{4}$ [60]. The values of $R_{p}$ are determined by the Stern-Geary equation, $R_{p}=\beta_{a} \beta_{c} /\left[2.303 I_{\text {corr }}\left(\beta_{a}+\beta_{c}\right)\right]$, utilizing the straight segments near to $E_{\text {corr }}$ of the curves. The values of $C R\left(n\right.$ year $\left.{ }^{-1}\right)$ are determined by $\mathrm{CR}=3272\left[\mathrm{I}_{\text {corr }} \times \mathrm{W} /(\mathrm{ECSA} \times \mathrm{d})\right]$, whereas $\mathrm{EW}$ and $\mathrm{d}$ represent the equiv-

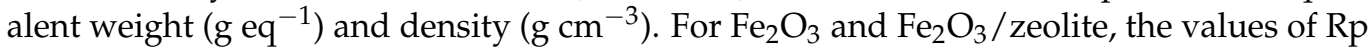
and CR are reported in Table 3. The Rp values are increased from 847.66 to $864.98 \Omega \mathrm{cm}^{2}$, whereas CR is decreased from 15.02 to $7.61 \mathrm{pm} \mathrm{Year}^{-1}$ by loading $\mathrm{Fe}_{2} \mathrm{O}_{3}$ on zeolite host. Therefore, photocorrosion is suppressed by the loading of the $\mathrm{Fe}_{2} \mathrm{O}_{3}$ photocatalyst into zeolite [61]. This is because zeolite can provide specific photophysical properties such as preventing the $\mathrm{Fe}_{2} \mathrm{O}_{3}$ nanoparticles from aggregating and improving their stability against sinterisation. The above-mentioned corrosion metrics show a significant improvement 
of the $\mathrm{Fe}_{2} \mathrm{O}_{3}$ photocatalyst's stability through the use of zeolite as catalyst support. The obtained $\mathrm{CR}$ values outperform any prior $\mathrm{Fe}_{2} \mathrm{O}_{3}$-based PEC electrode results $[62,63]$.

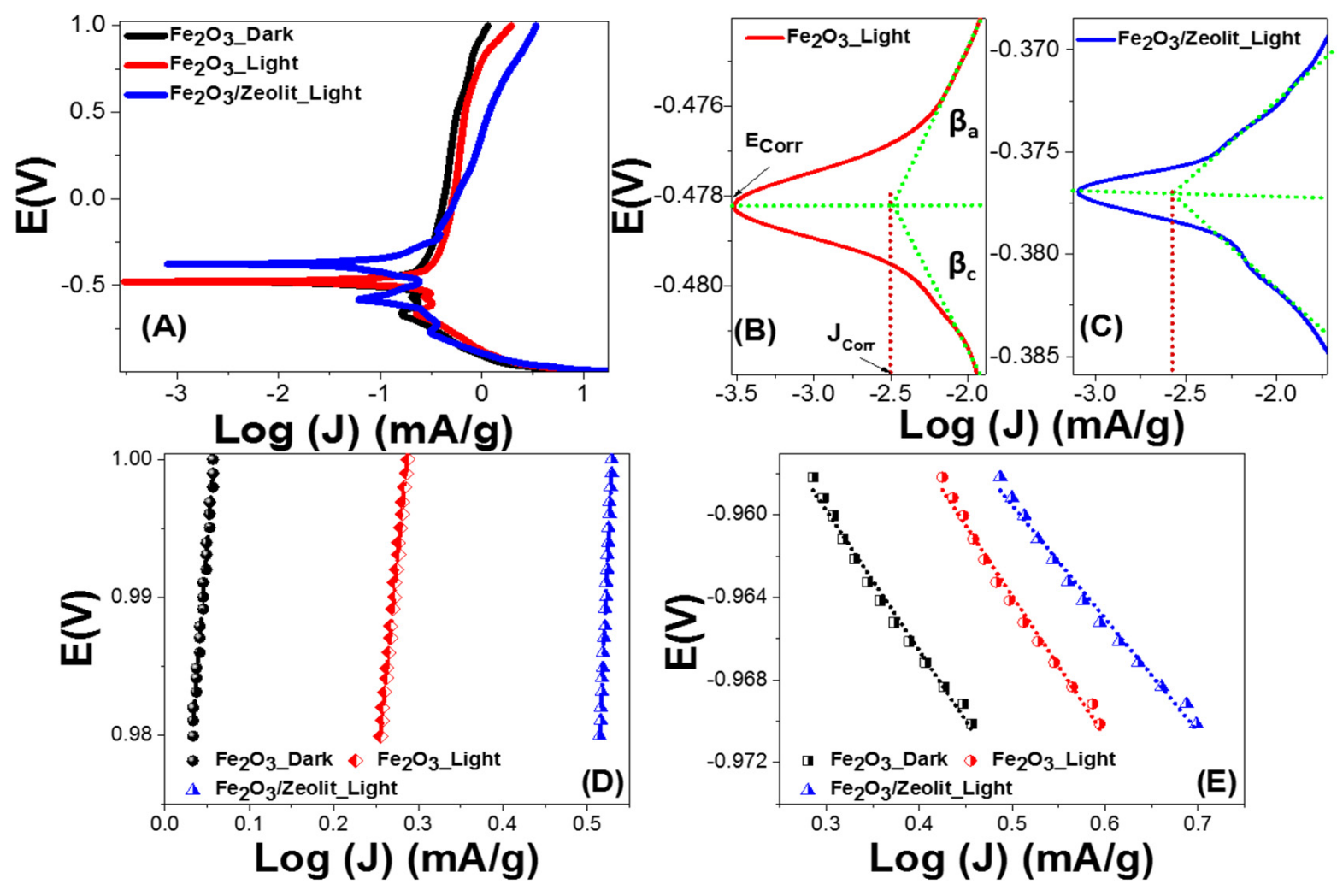

Figure 8. Combined anodic and cathodic polarization of $\mathrm{Fe}_{2} \mathrm{O}_{3}$ and $\mathrm{Fe}_{2} \mathrm{O}_{3}$ / zeolite (A), $\mathrm{E}_{\text {corr }}$ and $\mathrm{J}_{\text {corr }}$ of $(\mathbf{B}) \mathrm{Fe}_{2} \mathrm{O}_{3}$ and (C) $\mathrm{Fe}_{2} \mathrm{O}_{3}$ /zeolite; calculation of (D) anodic $\left(\beta_{\mathrm{a}}\right)$ and (E) cathodic $\left(\beta_{\mathrm{c}}\right)$ Tafel slopes.

\section{Conclusions}

A highly effective recycling technique for rusted iron wastes and a scalable method for the preparation of $\mathrm{Fe}_{2} \mathrm{O}_{3}$ and $\mathrm{Fe}_{2} \mathrm{O}_{3}$ /zeolite nanocomposite have been reported. The $\mathrm{Fe}_{2} \mathrm{O}_{3}$ /zeolite nanocomposite showed smaller sizes, more homogeneous nanopore diameter distribution, greater Vis/NIR light absorption capability, and a wider bandgap than $\mathrm{Fe}_{2} \mathrm{O}_{3}$ nanopowder. $\mathrm{Fe}_{2} \mathrm{O}_{3}$ /zeolite nanocomposite was applied successfully as a low-cost nanophotocatalyst. The application of $\mathrm{Fe}_{2} \mathrm{O}_{3}$ /zeolite for photoelectrocatalytic hydrogen production showed a production rate of $154.45 \mathrm{mmol} \mathrm{g}^{-1} \mathrm{~h}^{-1}$ at $1 \mathrm{~V}$ in $0.9 \mathrm{M} \mathrm{KOH}$ solution, which is the highest value yet for $\mathrm{Fe}_{2} \mathrm{O}_{3}$-based photocatalysts. The photocurrent density of $\mathrm{Fe}_{2} \mathrm{O}_{3}$ /zeolite is almost 2-fold that of the $\mathrm{Fe}_{2} \mathrm{O}_{3}$ catalyst, and the IPCE\% reached $\sim 27.34 \% @ 307 \mathrm{~nm}$ and $1 \mathrm{~V} \mathrm{~nm}$. This nanophotocatalyst has also shown remarkable stability with a very low PEC corrosion rate of $7.6 \mathrm{pm} /$ year. Additionally, it can retain $\sim 97 \%$ of its initial performance.

Supplementary Materials: The following are available online at https: / www.mdpi.com/article / 10.3390 / nano11123445/s1, Figure S1: FT-IR spectra of $\mathrm{Fe}_{2} \mathrm{O}_{3}$, zeolite, and $\mathrm{Fe}_{2} \mathrm{O}_{3}$ / zeolite nanocomposite. Figure S2: Variation of current density (J) for $\mathrm{Fe}_{2} \mathrm{O}_{3}$ (I), (II), and (III) under white light illumination and at $1 \mathrm{~V}$. Figure S3: Variation of current density (J) for $\mathrm{Fe}_{2} \mathrm{O}_{3}$ (III)/zeolite photoelectrodes with different $\mathrm{Fe}_{2} \mathrm{O}_{3}$ (III)/ zeolite weight ratios at $1 \mathrm{~V}$ under white light illumination.

Author Contributions: Conceptualization, F.M., A.M.A. and M.S.; methodology, F.M., A.M.A. and M.S.; validation, F.M., A.M.A. and M.S.; formal analysis, F.M., A.M.A. and M.S.; investigation, F.M., A.M.A. and M.S.; resources, F.M., A.M.A., M.B. and M.S.; data curation, F.M., A.M.A. and M.S.; writing-original draft preparation, F.M., A.M.A. and M.S.; writing-review and editing, F.M., A.M.A., M.B. and M.S.; visualization, F.M., A.M.A. and M.S.; project administration, F.M., A.M.A., 
M.B. and M.S.; funding acquisition, F.M., A.M.A., M.B. and M.S. All authors have read and agreed to the published version of the manuscript.

Funding: This research received no external funding.

Institutional Review Board Statement: Not applicable.

Informed Consent Statement: Not applicable.

Data Availability Statement: Not applicable.

Conflicts of Interest: The authors declare no conflict of interest.

\section{References}

1. Mehaney, A.; Shehatah, A.A.; Ahmed, A.M. Modeling of phononic crystal cavity for sensing different biodiesel fuels with high sensitivity. Mater. Chem. Phys. 2021, 257, 123774. [CrossRef]

2. Mehaney, A.; Ahmed, A.M. Theoretical design of porous phononic crystal sensor for detecting $\mathrm{CO}_{2}$ pollutions in air. Phys. $E$ Low-Dimens. Syst. Nanostructures 2020, 124, 114353. [CrossRef]

3. Zayed, M.; Ahmed, A.M.; Shaban, M. Synthesis and characterization of nanoporous $\mathrm{ZnO}$ and $\mathrm{Pt} / \mathrm{ZnO}$ thin films for dye degradation and water splitting applications. Int. J. Hydrog. Energy 2019, 44, 17630-17648. [CrossRef]

4. Rabia, M.; Mohamed, S.H.; Zhao, H.; Shaban, M.; Lei, Y.; Ahmed, A.M. TiO $2 / \mathrm{TiO}_{x} \mathrm{NY}$ hollow mushrooms-like nanocomposite photoanode for hydrogen electrogeneration. J. Porous Mater. 2020, 27, 133-139. [CrossRef]

5. Pourtaheri, A.; Nezamzadeh-Ejhieh, A. Enhancement in photocatalytic activity of NiO by supporting onto an Iranian clinoptilolite nano-particles of aqueous solution of cefuroxime pharmaceutical capsule. Spectrochim. Acta Part A Mol. Biomol. Spectrosc. 2015, 137, 338-344. [CrossRef]

6. Lassoued, A.; Lassoued, M.S.; Dkhil, B.; Ammar, S.; Gadri, A. Photocatalytic degradation of methylene blue dye by iron oxide $\left(\alpha-\mathrm{Fe}_{2} \mathrm{O}_{3}\right)$ nanoparticles under visible irradiation. J. Mater. Sci. Mater. Electron. 2018, 29, 8142-8152. [CrossRef]

7. Khedr, M.H.; Abdel Halim, K.S.; Soliman, N.K. Synthesis and photocatalytic activity of nano-sized iron oxides. Mater. Lett. 2009, 63, 598-601. [CrossRef]

8. Mishra, M.; Chun, D.M. $\alpha-\mathrm{Fe}_{2} \mathrm{O}_{3}$ as a photocatalytic material: A review. Appl. Catal. A Gen. 2015, 498, 126-141. [CrossRef]

9. Kanakaraju, D.; Kockler, J.; Motti, C.A.; Glass, B.D.; Oelgemöller, M. Titanium dioxide/zeolite integrated photocatalytic adsorbents for the degradation of amoxicillin. Appl. Catal. B Environ. 2015, 166-167, 45-55. [CrossRef]

10. Abukhadra, M.R.; Mohamed, A.S. Adsorption Removal of Safranin Dye Contaminants from Water Using Various Types of Natural Zeolite. Silicon 2019, 11, 1635-1647. [CrossRef]

11. Wang, S.; Li, H.; Xie, S.; Liu, S.; Xu, L. Physical and chemical regeneration of zeolitic adsorbents for dye removal in wastewater treatment. Chemosphere 2006, 65, 82-87. [CrossRef]

12. Shaban, M.; AbuKhadra, M.R.; Nasief, F.M.; Abd El-Salam, H.M. Removal of Ammonia from Aqueous Solutions, Ground Water, and Wastewater Using Mechanically Activated Clinoptilolite and Synthetic Zeolite-A: Kinetic and Equilibrium Studies. Water Air Soil Pollut. 2017, 228, 1-16. [CrossRef]

13. Shaban, M.; Abukhadra, M.R.; Shahien, M.G.; Ibrahim, S.S. Novel bentonite/zeolite-NaP composite efficiently removes methylene blue and Congo red dyes. Environ. Chem. Lett. 2018, 16, 275-280. [CrossRef]

14. Zhao, J.H.; Wang, Y.; Tang, X.; Li, Y.H.; Liu, F.T.; Zhang, Y.; Li, K. Enhanced photocatalytic hydrogen evolution over bimetallic zeolite imidazole framework-encapsulated CdS nanorods. Dalt. Trans. 2019, 48, 3560-3565. [CrossRef] [PubMed]

15. Yue, P.; Khan, F. Methods for increasing photo-assisted production of hydrogen over titanium exchanged zeolites. Int. J. Hydrogen Energy 1991, 16, 609-613. [CrossRef]

16. Mendes, P.; Lapisardi, G.; Bouchy, C.; Rivallan, M.; Silva, J.M.; Ribeiro, M.F. Hydrogenating activity of Pt/zeolite catalysts focusing acid support and metal dispersion influence. Appl. Catal. A Gen. 2015, 504, 17-28. [CrossRef]

17. Zahmakiran, M.; Durap, F.; Özkar, S. Zeolite confined copper(0) nanoclusters as cost-effective and reusable catalyst in hydrogen generation from the hydrolysis of ammonia-borane. Int. J. Hydrogen Energy 2010, 35, 187-197. [CrossRef]

18. Satsangi, V.R.; Dass, S.; Shrivastav, R. Nanostructured $\alpha-\mathrm{Fe}_{2} \mathrm{O}_{3}$ in PEC Generation of Hydrogen. In On Solar Hydrogen $\mathcal{E}$ Nanotechnology; John Wiley \& Sons, Ltd.: Chichester, UK, 2010; pp. 349-397.

19. Tamirat, A.G.; Rick, J.; Dubale, A.A.; Su, W.N.; Hwang, B.J. Using hematite for photoelectrochemical water splitting: A review of current progress and challenges. Nanoscale Horiz. 2016, 1, 243-267. [CrossRef]

20. Norouzi, A.; Nezamzadeh-Ejhieh, A. $\alpha-\mathrm{Fe}_{2} \mathrm{O}_{3} / \mathrm{Cu}_{2} \mathrm{O}$ heterostructure: Brief characterization and kinetic aspect of degradation of methylene blue. Phys. B Condens. Matter 2020, 599, 412422. [CrossRef]

21. Keerthana, S.P.; Yuvakkumar, R.; Ravi, G.; Kumar, P.; Elshikh, M.S.; Hussein, H.A.; Abdulwahed, F.A.; Velauthapillai, D.A. Strategy to enhance the photocatalytic efficiency of $\alpha-\mathrm{Fe}_{2} \mathrm{O}_{3}$. Chemosphere 2021, 270, 129498. [CrossRef]

22. Jaafar, N.F.; Abdul Jalil, A.; Triwahyono, S.; Muhd Muhid, M.N.; Sapawe, N.; Satar, M.A.H.; Asaari, H. Photodecolorization of methyl orange over $\alpha-\mathrm{Fe}_{2} \mathrm{O}_{3}$-supported HY catalysts: The effects of catalyst preparation and dealumination. Chem. Eng. J. 2012, 191, 112-122. [CrossRef] 
23. Mhamane, D.; Kim, H.K.; Aravindan, V.; Roh, K.C.; Srinivasan, M.; Kim, K.B. Rusted iron wire waste into high performance anode $\left(\alpha-\mathrm{Fe}_{2} \mathrm{O}_{3}\right)$ for Li-ion batteries: An efficient waste management approach. Green Chem. 2016, 18, 1395-1404. [CrossRef]

24. Chen, F.; Li, Y.; Cai, W.; Zhang, J. Preparation and sono-Fenton performance of 4A-zeolite supported $\alpha$-Fe $\mathrm{O}_{2} \mathrm{O}_{3}$. J. Hazard. Mater. 2010, 177, 743-749. [CrossRef]

25. An, N.; Yu, Q.; Liu, G.; Li, S.; Jia, M.; Zhang, W. Complete oxidation of formaldehyde at ambient temperature over supported $\mathrm{Pt} / \mathrm{Fe}_{2} \mathrm{O}_{3}$ catalysts prepared by colloid-deposition method. J. Hazard. Mater. 2011, 186, 1392-1397. [CrossRef] [PubMed]

26. Mohamed, F.; Rabia, M.; Shaban, M. Synthesis and characterization of biogenic iron oxides of different nanomorphologies from pomegranate peels for efficient solar hydrogen production. J. Mater. Res. Technol. 2020, 9, 4255-4271. [CrossRef]

27. Ravishankar, S.; Balu, A.R.; Usharani, K.; Balamurugan, S.; Prabha, D.; Nagarethinam, V.S. Optical and magnetic properties of $\mathrm{PbS}$ thin films doped with $\mathrm{Fe}^{2+}$ ions. Optik 2017, 134, 121-127. [CrossRef]

28. Parmar, V.; Changela, K.; Srinivas, B.; Sankar, M.M.; Mohanty, S.; Panigrahi, S.K.; Hariharan, K.; Kalyanasundaram, D. Relationship between dislocation density and antibacterial activity of cryo-rolled and cold-rolled copper. Materials 2019, 12, 200. [CrossRef]

29. Van Vlack, L.H. Elements of Materials Science and Engineering, 6th ed.; Addison Wesley: Boston, MA, USA, 1989 ; Volume 156.

30. Na, K.; Somorjai, G.A. Hierarchically Nanoporous Zeolites and Their Heterogeneous Catalysis: Current Status and Future Perspectives. Catal. Lett. 2015, 145, 193-213. [CrossRef]

31. Tedla, H.; Díaz, I.; Kebede, T.; Taddesse, A.M. Synthesis, characterization and photocatalytic activity of zeolite supported $\mathrm{ZnO} / \mathrm{Fe}_{2} \mathrm{O}_{3} / \mathrm{MnO}_{2}$ nanocomposites. J. Environ. Chem. Eng. 2015, 3, 1586-1591. [CrossRef]

32. Garay-Rodríguez, M.E.; Gutiérrez-Arzaluz, M.; Mejía-Saavedra, J.; Carrizales-Yánez, L.; Mugica-Álvarez, V.; Torres-Rodríguez, M. Natural Mexican Zeolite Modified with Iron to Remove Arsenic Ions from Water Sources. Proceedings 2018, 2, 1312. [CrossRef]

33. Elsayed, H.A.; Sayed, H.; Taha, T.A.; Alharbi, A.G.; Alenad, A.M.; Alshammari, B.A.; Ahmed, A.M.; Mehaney, A.; Aly, A.H. Simple and efficient design towards a significant improvement of the optical absorption of amorphous silicon solar cell. J. Quant. Spectrosc. Radiat. Transf. 2021, 275, 107890. [CrossRef]

34. Ahmed, A.M.; Mehaney, A.; Elsayed, H.A. Detection of toluene traces in exhaled breath by using a 1D PC as a biomarker for lung cancer diagnosis. Eur. Phys. J. Plus 2021, 136, 1-14. [CrossRef]

35. Cao, Z.; Qin, M.; Jia, B.; Gu, Y.; Chen, P.; Volinsky, A.A.; Qu, X. One pot solution combustion synthesis of highly mesoporous hematite for photocatalysis. Ceram. Int. 2015, 41, 2806-2812. [CrossRef]

36. Mahadik, M.; Shinde, S.; Mohite, V.; Kumbhar, S.; Rajpure, K.; Moholkar, A.; Kim, J.; Bhosale, C. Photoelectrocatalytic oxidation of Rhodamine B with sprayed $\alpha-\mathrm{Fe}_{2} \mathrm{O}_{3}$ photocatalyst. Mater. Express 2013, 3, 247-255. [CrossRef]

37. Duret, A.; Grätzel, M. Visible light-induced water oxidation on mesoscopic $\alpha-\mathrm{Fe}_{2} \mathrm{O}_{3}$ films made by ultrasonic spray pyrolysis. J. Phys. Chem. B 2005, 109, 17184-17191. [CrossRef]

38. Souza, F.L.; Lopes, K.P.; Nascente, P.A.P.; Leite, E.R. Nanostructured hematite thin films produced by spin-coating deposition solution: Application in water splitting. Sol. Energy Mater. Sol. Cells 2009, 93, 362-368. [CrossRef]

39. Derikvandi, H.; Nezamzadeh-Ejhieh, A. Designing of experiments for evaluating the interactions of influencing factors on the photocatalytic activity of $\mathrm{NiS}$ and $\mathrm{SnS}_{2}$ : Focus on coupling, supporting and nanoparticles. J. Colloid Interface Sci. 2017, 490, 628-641. [CrossRef]

40. Ahmed, A.M.; Mohamed, F.; Ashraf, A.M.; Shaban, M.; Aslam Parwaz Khan, A.; Asiri, A.M. Enhanced photoelectrochemical water splitting activity of carbon nanotubes@ $\mathrm{TiO}_{2}$ nanoribbons in different electrolytes. Chemosphere 2020, 238, 124554. [CrossRef]

41. Souza, F.L.; Lopes, K.P.; Longo, E.; Leite, E.R. The influence of the film thickness of nanostructured $\alpha$-Fe ${ }_{2} \mathrm{O}_{3}$ on water photooxidation. Phys. Chem. Chem. Phys. 2009, 11, 1215-1219. [CrossRef] [PubMed]

42. Pradhan, D.; Leung, K.T. Controlled growth of two-dimensional and one-dimensional ZnO nanostructures on indium tin oxide coated glass by direct electrodeposition. Langmuir 2008, 24, 9707-9716. [CrossRef]

43. Khosroabadi, A.A.; Gangopadhyay, P.; Duong, B.; Thomas, J.; Sigdel, A.K.; Berry, J.J.; Gennett, T.; Peyghambarian, N.; Norwood, R.A. Fabrication, electrical and optical properties of silver, indium tin oxide (ITO), and indium zinc oxide (IZO) nanostructure arrays. Phys. Status Solidi 2013, 210, 831-838. [CrossRef]

44. Kalska-Szostko, B.; Wykowska, U.; Piekut, K.; Zambrzycka, E. Stability of iron (Fe) nanowires. Colloids Surfaces A Physicochem. Eng. Asp. 2013, 416, 66-72. [CrossRef]

45. Saharan, P.; Chaudhary, G.R.; Mehta, S.K.; Umar, A. Removal of water contaminants by iron oxide nanomaterials. J. Nanosci. Nanotechnol. 2014, 14, 627-643. [CrossRef]

46. Ismail, A.A.; Mohamed, R.M.; Fouad, O.A.; Ibrahim, I.A. Synthesis of nanosized ZSM-5 using different alumina sources. Cryst. Res. Technol. 2006, 41, 145-149. [CrossRef]

47. Mohapatra, M.; Mohapatra, L.; Singh, P.; Anand, S.; Mishra, B. A comparative study on Pb(II), Cd(II), Cu(II), Co(II) adsorption from single and binary aqueous solutions on additive assisted nano-structured goethite. Int. J. Eng. Sci. Technol. 2011, 2, 89-103. [CrossRef]

48. Derikvandi, H.; Nezamzadeh-Ejhieh, A. Increased photocatalytic activity of $\mathrm{NiO}$ and $\mathrm{ZnO}$ in photodegradation of a model drug aqueous solution: Effect of coupling, supporting, particles size and calcination temperature. J. Hazard. Mater. 2017, 321, 629-638. [CrossRef] [PubMed]

49. Dutta, P.K.; Turbeville, W. Intrazeolitic photoinduced redox reactions between Ru(bpy) ${ }^{32+}$ and methylviologen. J. Phys. Chem. 1992, 96, 9410-9416. [CrossRef] 
50. Dubey, N.; Rayalu, S.S.; Labhsetwar, N.K.; Devotta, S. Visible light active zeolite-based photocatalysts for hydrogen evolution from water. Int. J. Hydrogen Energy 2008, 33, 5958-5966. [CrossRef]

51. Corma, A.; Garcia, H. Zeolite-based photocatalysts. Chem. Commun. 2004, 4, 1443-1459. [CrossRef]

52. Chica, A. Zeolites: Promised Materials for the Sustainable Production of Hydrogen. ISRN Chem. Eng. 2013, 2013, 1-19. [CrossRef]

53. Ghattavi, S.; Nezamzadeh-Ejhieh, A. GC-MASS detection of methyl orange degradation intermediates by $\mathrm{AgBr} / \mathrm{g}-\mathrm{C}_{3} \mathrm{~N}_{4}$ : Experimental design, bandgap study, and characterization of the catalyst. Int. J. Hydrogen Energy 2020, 45, 24636-24656. [CrossRef]

54. Aboud, A.A.; Shaban, M.; Revaprasadu, N. Effect of $\mathrm{Cu}, \mathrm{Ni}$ and $\mathrm{Pb}$ doping on the photo-electrochemical activity of $\mathrm{ZnO}$ thin films. RSC Adv. 2019, 9, 7729-7736. [CrossRef]

55. Jiang, C.; Moniz, S.J.A.; Wang, A.; Zhang, T.; Tang, J. Photoelectrochemical devices for solar water splitting-materials and challenges. Chem. Soc. Rev. 2017, 46, 4645-4660. [CrossRef]

56. Choudhary, S.; Upadhyay, S.; Kumar, P.; Singh, N.; Satsangi, V.R.; Shrivastav, R.; Dass, S. Nanostructured bilayered thin films in photoelectrochemical water splitting-A review. Int. J. Hydrogen Energy 2012, 37, 18713-18730. [CrossRef]

57. Anis, S.F.; Hashaikeh, R. Electrochemical water splitting using nano-zeolite Y supported tungsten oxide electrocatalysts. J. Nanoparticle Res. 2018, 20,1-11. [CrossRef]

58. Patel, M.; Park, W.H.; Ray, A.; Kim, J.; Lee, J.H. Photoelectrocatalytic sea water splitting using Kirkendall diffusion grown functional $\mathrm{Co}_{3} \mathrm{O}_{4}$ film. Sol. Energy Mater. Sol. Cells 2017, 171, 267-274. [CrossRef]

59. Shaban, M.; Kholidy, I.; Ahmed, G.M.; Negem, M.; Abd El-Salam, H.M. Cyclic voltammetry growth and characterization of Sn-Ag alloys of different nanomorphologies and compositions for efficient hydrogen evolution in alkaline solutions. RSC Adv. 2019, 9, 22389-22400. [CrossRef]

60. Kim, Y.-S.; Kim, J.-G. Corrosion Behavior of Pipeline Carbon Steel under Different Iron Oxide Deposits in the District Heating System. Metals 2017, 7, 182. [CrossRef]

61. White, J.C.; Dutta, P.K. Assembly of nanoparticles in zeolite y for the photocatalytic generation of hydrogen from water. J. Phys. Chem. C 2011, 115, 2938-2947. [CrossRef]

62. Otani, K.; Sakairi, M. Effects of metal cations on corrosion of mild steel in model fresh water. Corros. Sci. 2016, 111, 302-312. [CrossRef]

63. Kleiman-Shwarsctein, A.; Hu, Y.S.; Forman, A.J.; Stucky, G.D.; McFarland, E.W. Electrodeposition of $\alpha$-Fe ${ }_{2} \mathrm{O}_{3}$ doped with Mo or $\mathrm{Cr}$ as photoanodes for photocatalytic water splitting. J. Phys. Chem. C 2008, 112, 15900-15907. [CrossRef] 